\title{
$\theta 2-228$
}

Progress Report on Evaluation of Potential Impact of ${ }^{14} \mathrm{C}$ Releases from an HTGR Reprocessing Facility
G. G. Killough
K. R. Dixon
N. T. Edwards
B. D. Murphy
P. S. Rohwer
W. F. Harris
S. V. Kaye 


\section{DISCLAIMER}

This report was prepared as an account of work sponsored by an agency of the United States Government. Neither the United States Government nor any agency Thereof, nor any of their employees, makes any warranty, express or implied, or assumes any legal liability or responsibility for the accuracy, completeness, or usefulness of any information, apparatus, product, or process disclosed, or represents that its use would not infringe privately owned rights. Reference herein to any specific commercial product, process, or service by trade name, trademark, manufacturer, or otherwise does not necessarily constitute or imply its endorsement, recommendation, or favoring by the United States Government or any agency thereof. The views and opinions of authors expressed herein do not necessarily state or reflect those of the United States Government or any agency thereof. 


\section{DISCLAIMER}

Portions of this document may be illegible in electronic image products. Images are produced from the best available original document. 
Printed in the United States of America. Available from

National Technical Information Service

U.S. Department of Commerce

5285 Port Royal Road, Springfield, Virginia 22161

Price: Printed Copy $\$ 0$; Microfiche $\$ 2.25$

$$
5.00
$$

This report was prepared as an account of work sponsored by the United States Government. Neither the United States nor the Energy Research and Development Administration/United States Nuclear Regulatory Commission, nor any of their employees, nor any of their contractors, subcontractors, or their employees, makes dny warranty, express or implied, or assumes any legal liability or responsibility for the accuracy, completeness or usefulness of any information, apparatus, product or process disclosed, or represents that its use would not infringe privately owned rights. 
ORNL/TM-5284

UC $-41, U C-77$

Contract No. W-7405-eng-26

Environmental Sciences Division

PROGRESS REPORT ON EVALUATION OF POTENTIAL IMPACT OF

${ }^{14} \mathrm{C}$ RELEASES FROM AN HTGR REPROCESSING FACILITY
G. G. Killough
K. R. Dixon
N. T. Edwards
B. D. Murphy
P. S. Rohwer
W. F. Harris
S. V. Kaye

\section{JULY 1976}

Environmental Sciences Division Publication No. 838

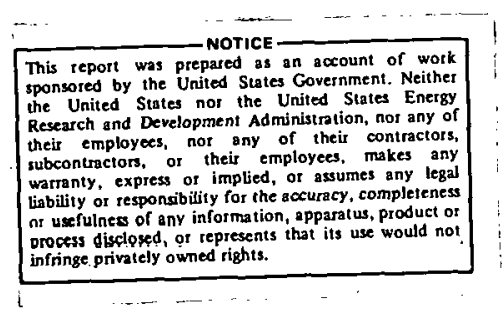

OAK RIDGE NATIONAL LABORATORY

Oak Ridge, Tennessee 37830

operated by

UNION CARBIDE CORPORATION

for the

ENERGY RESEARCH AND DEVELOPMENT ADMINISTRATION 
THIS PAGE

\section{WAS INTENTIONALLY LEFT BLANK}




\section{Foreword}

The release of ${ }^{14} \mathrm{C}$ into the atmosphere from HTGR fuel reprocessing facilities has long been considered a potential source of difficulty in licensing such facilities. Some preliminary work on this problem has been done by General Atomic Company $(G A C)^{a}$ and Oak Ridge National Laboratory's (ORNL) Chemical Technology Division. The GAC work was inconclusive with respect to the environmental acceptability of ${ }^{14} \mathrm{C}$ releases from $H T G R$ reprocessing. The GAC report concluded that the amount of ${ }^{14} \mathrm{C}$ released into the atmosphere during the period 1985 and 2035 from reprocessing plants would be considerably less than the amount from natural production during the same period; and that the amount produced would also be considerably less than the amount of ${ }^{14} \mathrm{C}$ produced by weapons testing during the 1950 s and 1960 s. The report also concluded that ${ }^{14} \mathrm{C}$ was rapidly removed from the atmosphere, eventually ending up in deep ocean reservoirs. One of the report's recommendations was the investigation of methods of carbon fixation as part of the reprocessing development work.

The pursuit of carbon fixation as a serious alternative to atmospheric release could introduce a significant financial perturbation into the development program. Therefore, a more definitive assessment of the need for carbon fixation was felt to be desirable. Furthermore, it was felt that this assessment should include an investigation by professional environmental researchers, rather than reflecting only the point of view of reprocessing development engineers, as had been the case with

\footnotetext{
${ }^{a}$ GA-A13174, Ref. 4 in the References section of this report.
} 
previous ORNL and GAC studies. In addition to their expertise in the relevant basic sciences, the environmental scientists bring to the study a familiarity with the language and concerns of those who will be involved in the licensing of reprocessing plants.

Early in FY 1975 a two-phase program was undertaken to study the ${ }^{14} \mathrm{C}$ problem in depth. This work was funded from Subtask 310 of the Thorium Utilization Program and is being accomplished in the ORNL Environmental Sciences Division. The two phases are (1) a regional assessment (within 50 miles of the reprocessing plant), which was completed at the end of FY 1975; and (2) an assessment of the worldwide impact of ${ }^{14} \mathrm{C}$ releases, scheduled for completion during FY 1976. The principal objective of this program is to establish a defensible ORNL position on ${ }^{14} \mathrm{C}$ releases to guide the reprocessing development program. This document reports results for the first phase of the study; a final report will be published at the end of FY 1976.

The starting point of llie assessment described in this report is an assumed release of ${ }^{14} \mathrm{CO}_{2}$ to the atmosphere. In-plant engineering studies which might lead to the mitigation of the spread of ${ }^{14} \mathrm{C}$ from a reprocessing facility were considered to be outside the scope of this report. Calculated radiation doses to individuals and the population within 50 miles of the facility are presented; these doses are hased on new dosimetric factors for ${ }^{14} \mathrm{C}$ computed for the study from recently published metabolic and dosimetric data. To predict time-averaged concentrations of ${ }^{14} \mathrm{C}$ in the air at various locations for dosimetric calculations, Oak Ridge area meteorology was used with a Gaussian plume atmospheric dispersion model. Other aspects of the study, however, such as 
the regional distribution of population and food-production sources, are not site specific.

The uptake and retention of ${ }^{14} \mathrm{C}$ by vegetation near the reprocessing facility were studied with a plant carbon assimilation model. Combinations of meteorological conditions leading to occurrences of elevated ambient concentrations of ${ }^{14} \mathrm{C}$ were simulated with a Monte Carlo technique, with probability distributions appropriate to the hypothesized meteorology. The results of these calculations suggest that plant tissues might reach a specific activity in excess of the time-averaged ambient specific activity. At present, however, this result should be regarded as tentative and lacking direct experimental confirmation; but it serves to raise a question whose importance to the HTGR technology calls for further investigation.

The dose estimates presented in this report are probably higher than those that would result from comparable site-specific analyses applied to many potential real sites. But within the context of the generic type of assessment described here, the models, analytical methods, and data bases are believed to be representative of the best information that is currently available. 
THIS PAGE

\section{WAS INTENTIONALLY \\ LEFT BLANK}


Abstract .................................. xi

1.0 Review and Analysis of Literature Related to Transport and Dosimetry of ${ }^{14} \mathrm{C}$

1.1 Introduction and Scope .............

1.2 Global Carbon Cycling ................ 1

1.2.1 Distribution of ${ }^{12} \mathrm{C}$ and ${ }^{14} \mathrm{C}$ among environmental reservoirs ............ . .

1.2.2 Estimates of introduction of excess ${ }^{14} \mathrm{C}$ into the atmosphere from nuclear tests and its distribution.

1.2.3 Analysis of the distribution of excess ${ }^{14} \mathrm{C}$ in the terrestrial biota.......... 10

1.3 Dosimetry Models and Parameters .......... 13

1.3.1 Reference individual for dose calculations ... 13

1.3.2 General equations of internal dosimetry.... 13

1.3.3 Review of metabolic models ......... 16

1.3.4 The specific activity method ........ . . 17

1.3.5 Relative contributions of inhalation and ingestion to the dose.............

1.3.6 Calculations of dose-rate factors for various internal organs.............. 21

1.3.6.1 Skeletal tissues ........... 24

1.3.6.2 Body fat . . . . . . . . . . 25

1.3.6.3 Gastrointestinal tract . . . . . . 25

1.3.7 External dose . . . . . . . . . . 26 
CONTENTS, continued

Page

2.0 Predictions of ${ }^{14} \mathrm{C}$ Transport and Cyclina in a model ecosystem. bordering a HTGR Reprocessing Facility . . . . . . . . 26

2.1 Source Term . . . . . . . . . . . . . 27

2.2 Carbon-14 Transport Calculations . . . . . . . . 27

2.2.1 The Atmospheric Transport Monel . . . . . . . . . 27

2.2.2 Hourly version of the Atmospheric Transport Model. 28

2.2.3 Atmospheric data . . . . . . . . . 28

2.2.3.1 Plume rise . . . . . . . . . 29

2.2.3.2 Dispersion parameters . . . . . . 29

2.2.3.3 Wind stability and speed classes .... 33

2.2.3.4 Basis for calculatina time averages ... 34

2.2.3.6 Episodic exrursinn ralculations .... 34

2.2.3.6 Diurnal pattern of stability classcs . . 35

2.2.4 Description of Carbon Assimilation Model (CAM) . . 38

2.2.4.1 Plant growth rate .......... 41

2.2.4.2 Leaf mortality rate......... 45

2.7.4.3 Leaf respiration rates . . . . . . 46

2.2.5 Incorporation of ${ }^{14} \mathrm{C}$ Concentration in the Carbon Assimilation Model (CAM) . . . . . . . . . 47

2.2.6 Estimates of ${ }^{14} \mathrm{C}$ Assimilation ........ . 51

3.0 Radiological Impacts to Individuals and Populations in the Vicinity of a HTGR Reprocessing Facility.......... 55

3.1 Exposure Scenarios . . . . . . . . . . 55

3.2 Dose to the Maximally Exposed Individual . . . . . . 58

3.3 Averaqe Individual Within the 10- and 10n-mile Squares . 60 
CONTENTS, continued

$\underline{\text { Page }}$

3.4 Local Population Dose . . . . . . . . . . . . . 61

4.0 Conclusions and Recommendations .......... . 62

References ............... 65

Appendix ......................... 71 


\section{THIS PAGE}

\section{WAS INTENTIONALLY LEFT BLANK}




\section{TABLES}

$\underline{\text { Table }}$

Page

1 A comparison of estimates of world reservoir sizes of ${ }^{12} \mathrm{C}$ and natural ${ }^{14} \mathrm{C}$ before nuclear testing....... . 4

2 A comparison of estimates of the carbon fluxes amona reservoirs...................... 5

3 Estimated ${ }^{14} \mathrm{C}$ yields to the atmosphere from nuclear testing between 1945 and 1969 ............. 8

4 Carbon pools and production for the various components of the terrestrial biosphere and estimates of ${ }^{14} \mathrm{C}$ content of the oceans in 1969 ..................... 11

5 Selected data for Reference Man . . . . . . . . . 14

6 Dose Rate Factors for ${ }^{14} \mathrm{C}$ computed from Snyder et a1. . . 22

7 Stack parameters used to calculate atmospheric disnersion of ${ }^{14} \mathrm{C}$ releases from a model HTRR fuel reprocessina plant 30

8 Maximum ground level concentrations of ${ }^{14} \mathrm{CO}_{2}$ for two stack. heights expressed as fraction by volume $\left(\mathrm{cm}^{3} / \mathrm{cm}^{3}\right)$. 48

9 Fractional daytime occurrence of important stability classes and wind speed conditions . . . . . . . . . 
FIFIJRES

1 Atmospheric levels of excess ${ }^{14} \mathrm{C}$ in the northern and southern hemisphere between 1953 and 1970 compared with excess ${ }^{14} \mathrm{C}$ levels in plants and milk products...

2 Increase in effective height of HThR stack as a function of exit gas temperature ..............

3 Maximum ground level cuncentrallun ds a runcliun of effective source height . . . . . . . . . . . 32

4 Plume centerline concentration for two HTGR fuel reprocessing plant desings as described in Table $7:$. .

5 Ground level atmospheric concentrations of ${ }^{14} \mathrm{CO}_{2}$ and ${ }^{14} \mathrm{C}$ content in leaves for five days during the growing season at $500 \mathrm{~m}$ from stack............ . 52

6 Environmental specific activities . . . . . . . . 53 


\section{ABSTRACT}

KILLOUGH, G. G., K. R. Dixon, N. T. Edwards, B. D. Murphy, P. S. Rohwer, W. F. Harris, and S.: V i Kaye. 1976. Progress report on evaluation of potential impact of ${ }^{14} \mathrm{C}$ releases from an HTGR reprocessing facility. ORNL/TM-5284. Oak Ridge National Laboratory, Oak Ridge, Tennessee. $80 \mathrm{pp}$.

The potential radiological impacts of atmospheric releases of ${ }^{14} \mathrm{CO}_{2}$ are assessed for a model HTGR reprocessing facility. Two off-gas systems were considered: (1) a 300-ft stack with no thermal output, and (2) a $1000-\mathrm{ft}$ stack with a stack gas temperature of $80^{\circ} \mathrm{C}$ and heat output of $4.2 \times 10^{7} \mathrm{Btu} / \mathrm{hr}$. Meteorological data for the Oak Ridge area were used with an assumed annual release rate of $5000 \mathrm{Ci}$ as input to an atmospheric transport model, which in turn was used to predict air concentrations of ${ }^{14} \mathrm{C}$ at points of habitation and food production in the local area (within 50 miles) of the facility. The total-body dose rates estimated for the average resident living in the $10 \mathrm{cal}$ area were $0.107 \mathrm{mrem} / \mathrm{yr}$ for the $300-\mathrm{ft}$ stack and $0.063 \mathrm{mrem} / \mathrm{yr}$ for the $1000-\mathrm{ft}$ stack. The estimated total-body dose to the "fence-post man" was $87 \mathrm{mrem} / \mathrm{yr}$ for the $300-\mathrm{ft}$ stack and 5.5 $\mathrm{mrem} / \mathrm{yr}$ for the $1000-\mathrm{ft}$ stack. Population doses were computed for a population of $10^{6}$ individuals uniformly distributed within the 50-mile local area of the facility; these were 110 man-rem for the 300-ft stack and 63 man-rem for the 1000-ft stack. The results of these dose calculations suggest that a 1000-ft stack would be very effective in reducing the estimated doses from the levels predicted for the $300-\mathrm{ft}$ stack.

An atmospheric transport model was used to drive a plant growth carbon assimilation model in order to investigate the adequacy of the assumption of tissue equilibration with time-averaged ambient specific activity 


$$
\text { xiv }
$$

as a basis for dose estimates. Simulation runs with these models suggest that in the presence of frequent fluctuations of large amplitude in the ambient air ${ }^{14} \mathrm{CO}_{2}$ concentrations, specific activity in plant tissue can exceed conventionally calculated time-averaged specific activity.

The significance of elevated plant specific activity to dose estimation must be evaluated together with other factors such as variation among local meteorologies, time of harvest and amount and type of plant consumed. 


\subsection{REVIEW AND ANALYSIS OF LITERATURE RELATED TO TRANSPORT AND DOSIMETRY OF ${ }^{14} \mathrm{C}$}

\subsection{Introduction and Scope}

Before an accurate assessment can be made of the fate of ${ }^{14} \mathrm{C}$ released into the atmosphere by man's activities, the amounts of natural ${ }^{12} \mathrm{C}$ and ${ }^{14} \mathrm{C}$ that are now present in the various world reservoirs must be determined. Also, the transfer rates of carbon between these reservoirs must be estimated. These estimates require measurements of carbon reservoirs, production and decay rates of various types of biota in the sea and on land, and the areal extent of each type. In Sec. 1.2 a survey of relevant literature is given, and uncertainties in the existing information are discussed.

The dosimetry of ${ }^{14} \mathrm{C}$ in man may be approached via metabolic models or specific activity calculations. The latter approach is appropriate for the present assessment and is developed in Sec. 1.3. Dose-rate factors based on recently published dosimetric information are derived in Sec. 1.3 and used for all dose calculations in this report.

\subsection{GTobal Carbon Cycling}

1.2.1 Distribution of ${ }^{12} \mathrm{C}$ and ${ }^{14} \mathrm{C}$ among environmental reservoirs

Some of the earliest estimates of world carbon budgets were made by Schroeder ${ }^{1}$ who reviewed earlier studies by Liebig ${ }^{2}$ and Ebermayer. ${ }^{3}$ The bases for these budgets were annual hay production in Europe, production of various food crops in different parts of the earth, and estimates of organic production in a Bavarian forest. Even though such estimates 
required very broad assumptions, world carbon budgets have recently been constructed using much of their data, which was collected in the nineteenth century. For example, a recent renort by Brooks, et al. 4 used data from Fairhall and Young ${ }^{5}$ which can be traced back through foldschmidt, ${ }^{6}$ Schroeder, ${ }^{1}$ Ebermayer, ${ }^{3}$, and Liebia. ${ }^{2}$

Through the use of computer modeling it is now possible to simulate global carbon cycling, and from such modeling efforts, to identify areas requiring more data and research. In recent years data have been uathered by numerous investigators on productiun rales and reservoir stzes of most environments of the world. For example, one of the major objectives of the International Biological Program was to measure organic matter production in major environments of the world. Throuah such intearated team efforts more realistic world carbon budgets are becomina available as data gathered in recent years are analyzed and published $\left(01\right.$ son $^{7}$; Lieth $\left.^{8}\right)$.

Conceptual models of the world carbon cycle published in the last 20 years consist of five to twelve compartments depending usually upon the amount of data available to the modeler. Craiq ${ }^{9}$ published a fivecompartment model of ${ }^{12} \mathrm{C}$ and ${ }^{14} \mathrm{C}$ using carbon data which can be traced back to the late 1800 's. A seven-compartment model developed by Machtal 10 gives little consideration to the contribution of the terrestrial exchanae of plants and dead orqanic matter and other parts of the model are oversimplified. The 10-reservoir model of Bolin 11 is a more comprehensive model, but like all models of global carbon cycling suffers from lack of complete data. Cramer and Myers ${ }^{12}$ have perhaps the most complete model exchange of $C$ between the sea and the atmosphere. Smil and Milton ${ }^{13} \mathrm{em}-$ phasized carbon emissions from fossil fuel combustion in their eight 
reservoir model and predicted changes in levels of carbon in the various reservoirs between the years 1960 and 2020 . Nyda $7^{14}$ constructed a 10reservoir world carbon model which treats northern and southern hemispheres separately, a feature especially adaptable to studyina ${ }^{14} \mathrm{C}$ releases from nuclear testing.

All of the models described above are hampered by a lack of complete data sets and the lack of a coordinated approach to compiling all of the avallable sources of data.

Data used in some of the models mentioned above are compared in Tables 1 and 2. Carbon pool sizes for specific reservoirs (Table 1) are not as variable as carbon transfers between compartments (Table 2). These discrepancies among values of carbon flux are due to insufficient data in many cases. and are often values which are generated by the particular model for balance purposes, and in many cases the values are little more than educated guesses. One of the most complete data sets given in Table 1 , that of Fairhall and Young, ${ }^{5}$ contains estimates of ${ }^{14} \mathrm{C}$ pool sizes as does that of Plesset and Latter. ${ }^{15}$ Data for ${ }^{12} \mathrm{C}$ of Fairhall and Young ${ }^{5}$ represent much earlier estimates dating back to the 18n0's. Because of changing land use and improved measurement techniques, more recently constructed world carbon budgets should provide better estimates of both ${ }^{12} \mathrm{C}$ and ${ }^{14} \mathrm{C}$ pool sizes. Data in Table 1 reported by SCEP ${ }^{16}$ represent intensive synthesis effort by numerous scientists from several disciplines. The accuracy of the estimates given is suspect, as was admitted by the SCEP working group, but are probably the best estimates that are currently available. The SCEP group recommended that an organized information system be developed and maintained to eliminate uncertainties in comparing 
Table 1. A comparison of estimates of world reservoir sizes of ${ }^{12} \mathrm{C}$ and natural ${ }^{14} \mathrm{C}$ be=ore nuclear testing. Values are given in $10^{9}$ metric tons for $12:$ and in metric tons for ${ }^{14} \mathrm{C}$ (shown in parenthesesi.

\begin{tabular}{|c|c|c|c|c|c|c|}
\hline \multirow{2}{*}{ Atmospheric } & \multicolumn{3}{|c|}{ Dcean } & \multicolumn{2}{|c|}{ Terrestrial } & \multirow{2}{*}{ Reference $^{a}$} \\
\hline & Mixed Layer & Deeo Ocean & $\begin{array}{l}\text { Marine } \\
\text { Biosphere }\end{array}$ & Biosphere & $\begin{array}{l}\text { Dead } \\
\text { Organic }\end{array}$ & \\
\hline 683 & 703 & & 2 & $82^{b}$ & $1498^{C}$ & SCEP 16 \\
\hline 700 & 500 & 34500 & $\begin{array}{l}3010 \\
\text { (Include:s } \\
\text { dead orqanic) }\end{array}$ & 450 & 700 & Bolin 11 \\
\hline 600 & 2700 & 33000 & . & - & & Machta 10 \\
\hline $642(0.825)$ & $770(0.958)$ & $37000(41.74)$ & $=$ & $306(0.379)$ & $1097(1.279)$ & Plesset and Latter ${ }^{15}$ \\
\hline $680(0.953)$ & $1820(1.65)$ & $380 \mathrm{C} 0(45.07)$ & $3(0.0046)$ & $310(0.418)$ & $1100(1.48 \pi)$ & Fairhall and Young 5 \\
\hline
\end{tabular}

${ }^{a}$ Complete citations are given in the List of References at the end of this report.

bIncludes leaves, litter, short-lived animals, algae.

${ }^{C}$ Includes wosd, large roots, and upper soil humus. 
Table 2. A comparison of estimates of the carbon fluxes among reservoirs. Values are in $10^{9}$ metric tons/year.

\begin{tabular}{|c|c|c|c|c|}
\hline & SCEP $^{16}$ & Bol in 11 & Machta 10 & $\begin{array}{l}\text { Plesset } \\
\text { and Latter } 15\end{array}$ \\
\hline Stratosphere to troposphere & & & 45 & \\
\hline Troposphere to stratosphere & & & 44 & . \\
\hline Troposphere to mixed layer & 21 & & 275 & 92 \\
\hline $\begin{array}{l}\text { Troposphere to terrestrial } \\
\text { biosphere }\end{array}$ & 56 & & $\longrightarrow$ & \\
\hline Mixed layer to troposphere & & & 270 & 91 \\
\hline Mixed layer to deep ocean & & 40 & 54 & 43 \\
\hline Mixed layer to marine biosphere & & 40 & $\longrightarrow$ & \\
\hline Deep ocean to mixed layer & & 45 & 21 & 43 \\
\hline Marine biota to mixed layer & - & 35 & 20 & 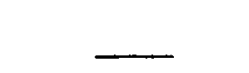 \\
\hline Marine biota to deep ocean & $\dot{-}$ & 5 & - & - \\
\hline $\begin{array}{l}\text { Terrestrial biota to } \\
\text { troposphere }\end{array}$ & & . & 310 & \\
\hline $\begin{array}{l}\text { Terrestrial biota to dead } \\
\text { organic }\end{array}$ & & 25 & 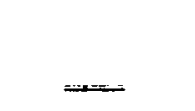 & 214 \\
\hline Dead organic to troposphere & & 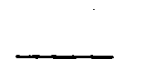 & 250 & 2 \\
\hline
\end{tabular}


techniques and results from scattered sources: They also recoanized the importance of including changing land use, such as deforestation, in development of budget models with which to assess carhon cycling.

1.2.2 Estimates of introduction of excess ${ }^{14} \mathrm{C}$ into the atmosphere from from nuclear tests and its distribution

Carbon-14 concentration in the atmosphere began to increase in the 1950 's in both the northern and southern hemisphere as a result of lowyield releases from nuclear testing (Fig. 1). This trend continued until mid-1959. The moratorium on atmospheric testina resulted in a sliaht decrease in ${ }^{14} \mathrm{C}$ levels in the northern hemisphere with a continued rise in ${ }^{14} \mathrm{C}$ concentration in the southern hemisphere. Detonation of nuclear devices in the atmosphere began aqain in 1961 and 1962, and the resumption is reflected in the peak ${ }^{14} \mathrm{C}$ concentrations in the atmosphere of the northern hemisphere in 1963. Low yield releases since 1962 are not reflected in measurements of a tmospheric ${ }^{14} \mathrm{C}$, probably because of the rapid movement of ${ }^{14} \mathrm{C}$ from the northern (where tests were conducted) to the southern hemisphere: By $1970,{ }^{14} \mathrm{C}$ concentrations in the southern hemisphere had almost equilibrated with the northern hemisphere at about $54 \%$ above natural (pre1950) ${ }^{14} \mathrm{C}$ concentrations.

A thorough investigation of the cyclina of ${ }^{14} \mathrm{C}$ from nuclear testing is the appropriate course to follow in order to assess global cycling of ${ }^{14} \mathrm{C}$ released from nuclear facilities. A first step in this investination is to quantify the ${ }^{14} \mathrm{C}$ released into the atmosphere from the nuclear tests. According to Walton et al., 17 a yield of 510.8 meatons had released $2130.6 \mathrm{~kg}$ of ${ }^{14} \mathrm{C}$ into the atmosphere (Table 3) by 1962 . Nearly $90 \%$ of this ${ }^{14} \mathrm{C}$ release was from air tests and less than $10 \%$ from surface tests. 


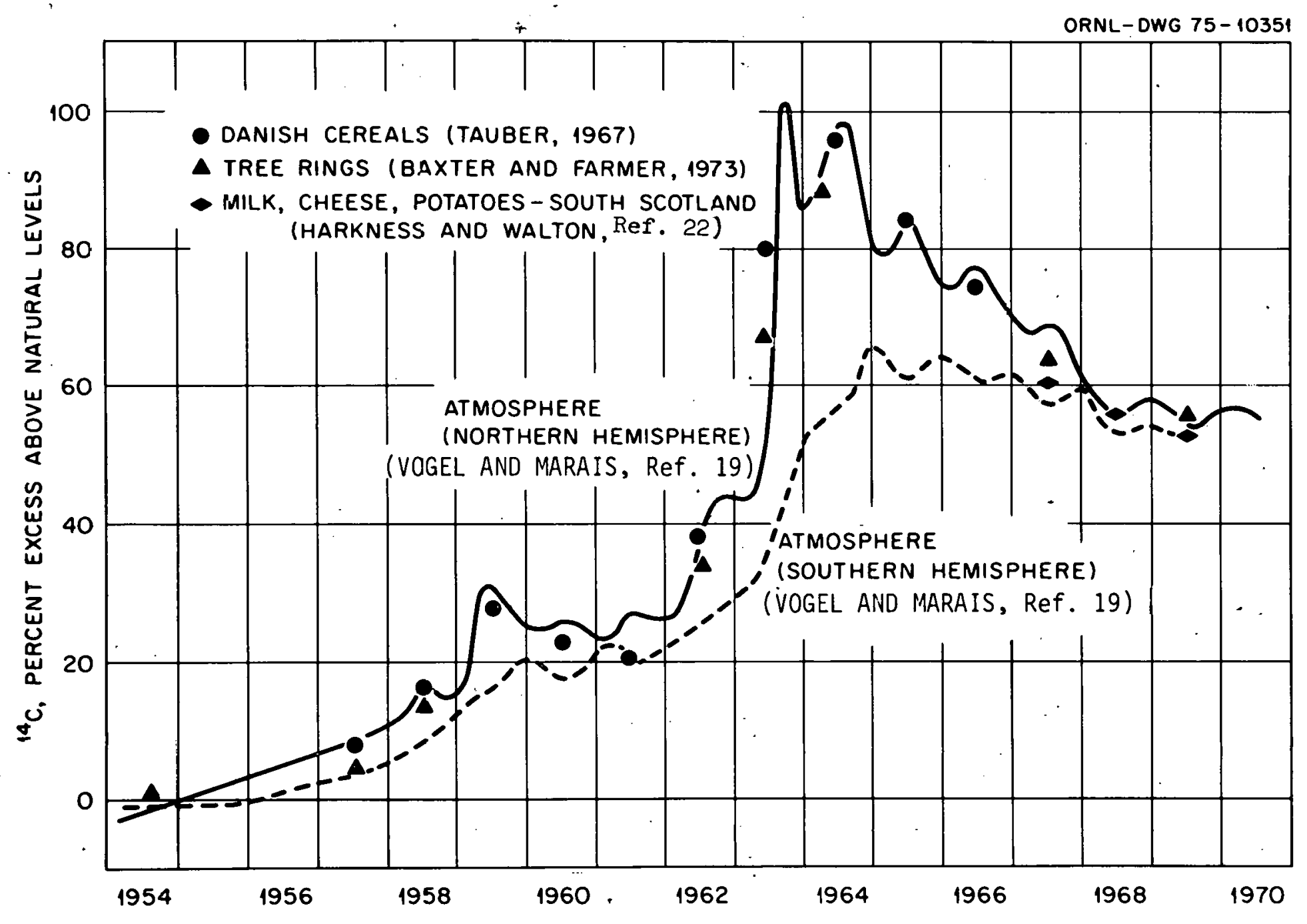

Fig. 1. Atmospheric levels of excess ${ }^{14} \mathrm{C}$ in the northern and southern hemispheres between 1953 and 1970 compared with excess $14 \mathrm{C}$ levels in plants and milk products. 
Table 3. Estimated ${ }^{14} \mathrm{C}$ yields to the atmosphere from nuclear testing between 1945 and 1969. Data through 1962 are from Walton et al.17 and data from 1967-69 are from Telegadas. 18

\begin{tabular}{|c|c|c|c|c|c|c|}
\hline \multirow[b]{2}{*}{ Period } & \multicolumn{2}{|c|}{ Air Tests } & \multicolumn{2}{|c|}{ Surface Tests } & \multicolumn{2}{|c|}{ Total } \\
\hline & $\begin{array}{l}\text { Yfald } \\
\text { (im tón) }\end{array}$ & $\begin{array}{l}{ }^{1 " r} \text {. Atomils } \\
\times 10^{27}\end{array}$ & $\begin{array}{l}\text { Yteld } \\
\text { (M ton) }\end{array}$ & $\begin{array}{c}{ }^{14} \mathrm{C} \text { Alui!!s } \\
\times 10^{27}\end{array}$ & $\begin{array}{c}{ }^{14} \mathrm{C} \text { Atoms } \\
\times 10^{27}\end{array}$ & $\begin{array}{l}{ }^{14} \mathrm{C} \\
\mathrm{kg}\end{array}$ \\
\hline $1945-51$ & 0.19 & 0.038 & 0.57 & 0.057 & 0.095 & 2.21 \\
\hline $1952-54$ & 1.0 & 0.2 & 59.0 & 5.9 & 6.1 & 141.74 \\
\hline $1955-56$ & 11.0 & 2.2 & 17.0 & 1.7 & 3.9 & 90.62 \\
\hline $1957-58$ & 57.0 & 11.4 & 28.0 & 2.8 & 14.2 & 329.95 \\
\hline $1959-60$ & & & Test Mo & atorium & & \\
\hline 1961 & 120.0 & 24.0 & & & 21.0 & 557.66 \\
\hline 1962 & 217.0 & 43.4 & & & 43.4 & 1008.43 \\
\hline 1967 & 3.0 & 0.6 & & & 0.6 & 13.94 \\
\hline 1968 & 4.0 & 0.8 & & & 0.8 & 18.59 \\
\hline 1969 & 3.0 & U. $\dot{b}$ & $\ldots$ & 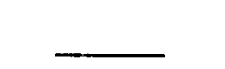 & 0.6 & 13.94 \\
\hline Tota1 & 416.19 & 83.24 & $104.5 \%$ & 10.46 & 93.7 & 2177.5 \\
\hline
\end{tabular}


An additional $46.9 \mathrm{~kg}$ of ${ }^{14} \mathrm{C}$ were released from nuclear device testing in the air between 1967 and 1969 (Telegadas ${ }^{18}$ ) for a total release through 1969 of $2177.5 \mathrm{~kg}$ of ${ }^{14} \mathrm{C}$. These values were calculated with the assumption that a one-megaton total-yield air burst introduces $2 \times 10^{26}{ }^{14} \mathrm{C}$ atoms into the atmosphere while a one-megaton yield surface burst introduces one-half this amount (Walton et al., ${ }^{17}$ Telegadas ${ }^{18}$ ). Fairhall and Young ${ }^{5}$ report a much smaller estimate of total ${ }^{14} \mathrm{C}$ yield $(1256 \mathrm{~kg})$ from nuclear tests through 1962 than is reported here and elsewhere. All calculations in the present report which involve ${ }^{14} \mathrm{C}$ yield data from weapon tests are based on the theoretical ${ }^{14} \mathrm{C}$ yields summarized in Table 3.

If we assume a pre-1950 specific activity in the atmosphere of 1.41 $\times 10^{-12} \mathrm{~g}^{14} \mathrm{C} / \mathrm{g}^{12} \mathrm{C}$ (Fairhall and Young ${ }^{5}$ ) and a total of $63 \times 10^{16} \mathrm{~g}^{12} \mathrm{C}$ in the atmosphere, we calculate that the natural (pre-1950) ${ }^{14} \mathrm{C}$ was $\simeq 958$ kg. Data from Telegadas ${ }^{18}$ show the excess ${ }^{14} \mathrm{C}$ (above 1950 natural levels) in the troposphere to be $\simeq 425 \mathrm{~kg}$ by the end of 1962 and $470 \mathrm{~kg}$ by the end of 1969. Thus only $\simeq 22 \%(470 / 2178)$ of the ${ }^{14} \mathrm{C}$ released into the atmosphere between 1945 and 1969 from nuclear tests was still in the troposphere in 1969. This is comparable to an estimate by Walton et al. ${ }^{20}$ of $20 \%$ of the excess ${ }^{14} \mathrm{C}$ remaining in the troposphere by July 1968 . Therefore, the remaining $78 \%(1710 \mathrm{~kg})$ must be in other reservoirs of the earth. Walton et al. ${ }^{20}$ could account for only about $610 \mathrm{~kg}$ in other reservoirs $(150 \mathrm{~kg}$ in the surface ocean, $260 \mathrm{~kg}$ in the biosphere, and $200 \mathrm{~kg}$ in the stratosphere). They placed the remaining $1100 \mathrm{~kg}$ in the deep ocean. Thus they assumed that over $50 \%$ of the total excess ${ }^{14} \mathrm{C}$ released from nuclear test had reached the deep ocean by 1969. This estimate of deep ocean excess ${ }^{14} \mathrm{C}$ is probably too high as the result of possible underestimation 
of ${ }^{14} \mathrm{C}$ retained in the terrestrial biosphere components (especially forests).

\subsubsection{Analysis of the distribution of excess ${ }^{14} \mathrm{C}$ in the terrestrial biota}

From available estimates of carbon pool sizes and production rates of the various terrestrial biosphere components (SCEP ${ }^{16}$ ) and specific activities of these components (Baxter and Farmer ${ }^{21}$; Harkness and Waiton ${ }^{22}$; Tauber ${ }^{23}$; and Godwin and Willis ${ }^{21}$ ) the amounts of natural ${ }^{11} \mathrm{C}$ and excess ${ }^{14} \mathrm{C}$ present in the terrestrial biota were calculated (Table 4). For example, ${ }^{14} \mathrm{C}$ concentrations in Danish cereals were $\simeq 35 \%$ above natural concentrations in 1962 (Tauber ${ }^{23}$ ) thus raising the specific activity to about $1.84 \times 10^{-12} \mathrm{~g}^{14} \mathrm{C} / \mathrm{g}^{12} \mathrm{C}$. Multiplying $1.84 \times 10^{-12}$ times the organic carbon pool in agricultural crops gives $303 \mathrm{~kg}$ of ${ }^{14} \mathrm{C}$ or $79 \mathrm{~kg}$ excess ${ }^{14} \mathrm{C}$ above the pre-1950 natural level of $224 \mathrm{~kg}$. Carbon-14 is accumulated in growth rings of trees with levels of ${ }^{14} \mathrm{C}$ activity in a particular growth ring equilibrated with the levels of ${ }^{14} \mathrm{C}$ in the atmosphere which existed during the time the ring was growing (Baxter and Farmer ${ }^{21}$ and Godwin and Willis $\left.{ }^{24}\right)$. Thus, it is necessary to calculate the amount of ${ }^{14} \mathrm{C}$ in forest and woody vegetation on a cumulative basis. The annual net primary production values for forest (SCEP ${ }^{16}$ ) were multiplied by ${ }^{14} \mathrm{C}$ specific activities for each year and accumulated to give the values in Table 4 . Using the above procedures we calculate that excess ${ }^{14} \mathrm{C}$ in the terrestrial biosphere was $356 \mathrm{~kg}$ in 1962 and $747 \mathrm{~kg}$ in 1969. This 1969 value is nearly 3 times higher than the value given by walton et al. ${ }^{20}$ for the terrestrial biosphere for the same year. Fairhall and Young ${ }^{5}$ reported 
Tabie 4. Carbon pools and froduction for the various components of the terrestrial biosphere (SCEP ${ }^{16}$ ) and estimates of ${ }^{14} \mathrm{C}$ content of the oceans in 1969. Pre-1950 levels of ${ }^{14} \mathrm{C}$ are based on specific activities taken from Fairhall and Young ${ }^{5}$ and ${ }^{14} \mathrm{C}$ amounts in the terrestrial components are based on specific activities calculated from Fig. 1 . Atmospheric ${ }^{14} \mathrm{C}$ estimates are from Telegadas. ${ }^{18}$ Values in parenthes is represent a lower bounds estimate for forests

in which $44 \%$ of each year's NPP has a long residence time and $56 \%$ of each year's NPP has a short ( 3 yrs) residence time (after SCEP16).

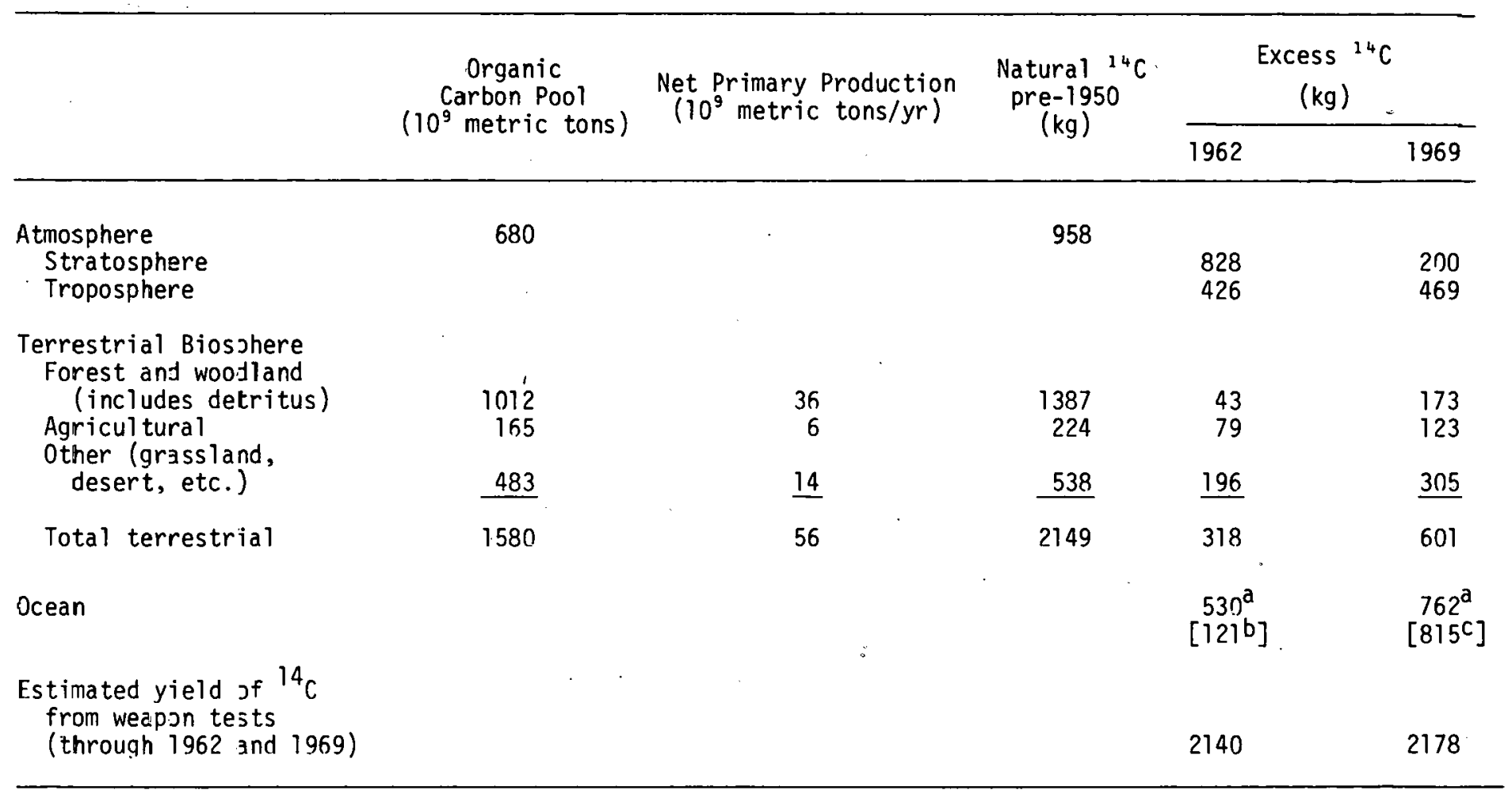

a Total in atmosphere + terrestrial minus estimated yield from weapon tests.

brom Fairhall and Young. 5

${ }^{C_{M}}$ Measured ${ }^{17} \mathrm{C}$ activity in sea water from Fairhall. ${ }^{26}$ 
only $23 \mathrm{~kg}$ of excess ${ }^{14} \mathrm{C}$ in the terrestrial biosphere in 1962 as compared to our estimate of $356 \mathrm{~kg}$. Our estimate does not subtract forest mortality and decay from forest net primary production and thus may be considered too high by the amount transferred annually to detritus, which is decomposed very slowly and released back into the atmosphere as ${ }^{14} \mathrm{CO}_{2}$. However, 01 son $^{7}$ has stated that even the highest values for terrestrial net primary production seem more likely to underestimate rather than overestimate. A recent estimate of forest and woodland net primary production by 01 son $^{25}$ puts the value at $59.4 \times 10^{9}$ metric tons of carbon per year (an amount considerably higher than the $36 \times 10^{9}$ value used in our calculations). If our estimates of excess ${ }^{14} \mathrm{C}$ in the terrestrial biosphere and detritus are added to other world reservoir estimates by Walton et al. ${ }^{20}$ we calculate that $\simeq 65 \%$ of the ${ }^{14} \mathrm{C}$ released from nuclear. tests through 1969 can be accounted for in the atmosphere, terrestrial biomass, and terrestrial detritus. This leaves $\simeq 35 \%(762 \mathrm{~kg})$ of ${ }^{14} \mathrm{C}$ in the oceans at the end of 1969. This is relatively close to A. W. Fairha17's ${ }^{26}$ estimate of $3.5 \times 10^{28}{ }^{14} \mathrm{C}$ atoms, which is equivalent to $\simeq 815$ $\mathrm{kg}$. Fairhall's estimate is based on extensive measurements of ${ }^{14} \mathrm{C}$ in sea water. If careful consideration is given to high levels of ${ }^{14} \mathrm{C}$ activity of the biota and soil in the immediate vicinity of nuclear test sites, estimatcs of cxcess ${ }^{14} \mathrm{C}$ in the deep ocean or other reservoirs may need adjustments. For example, Koranda ${ }^{27}$ reported relatively high concentrations of ${ }^{14} \mathrm{C}$ in the biota and soil near the detonation sites in the Pacific Proving Grounds (where nuclear devices were tested from 1948 to 1958), at times up to 12 years after the end of testing. Koranda reports that on Runit Island, outer growth rings contained concentrations of ${ }^{14} \mathrm{C} 78 \%$ 
above natura 1 , leaves $-125 \%$, 11 tter-204\% and so11-292\%. Thus, budgeting of ${ }^{14} \mathrm{C}$ from any source must consider the ${ }^{14} \mathrm{C}$ content in the immediate environment of the release before global budgets from such releases can be considered reliable.

\subsection{Dosimetry Models and Parameters}

\subsubsection{Reference individual for dose calculations}

The reference individual for whom doses are calculated is an adult male whose anatomical and physiological properties are defined and quantified by the Task Group on Reference Man of the International Commission on Radiological Protection (ICRP) in ICRP Publication $23 .{ }^{28}$ This document represents a distillation of biological information from many hundreds of sources and defines reference human beings to replace the older Standard $\mathrm{Man}^{29}$ concept. It seems probable that future ICRP Publications will present recommendations based on the dosimetry of Reference Man, and accordingly, information from ICRP Publication 23 has been utilized whereever possible. Table 5 presents a selection of Reference Man parameters.

\subsubsection{General equations of internal dosimetry}

In general, we may express the dose rate to an organ of the body which results from a given burden of a radionuclide in that organ, as

$$
\dot{D}(t)=S q(t) r e m / d a y
$$

where

$$
\begin{aligned}
\dot{D}(t)= & \text { the dose rate }(\text { rem } / \text { day }) \text { at time } t \text { to the reference organ; } \\
S= & \text { the dose per unit residence of the radionuclide in the ref- } \\
& \text { erence organ (rem } / \mu C i-d a y) ;
\end{aligned}
$$


Table 5. Selected data for Reference $\operatorname{Man}^{28}$

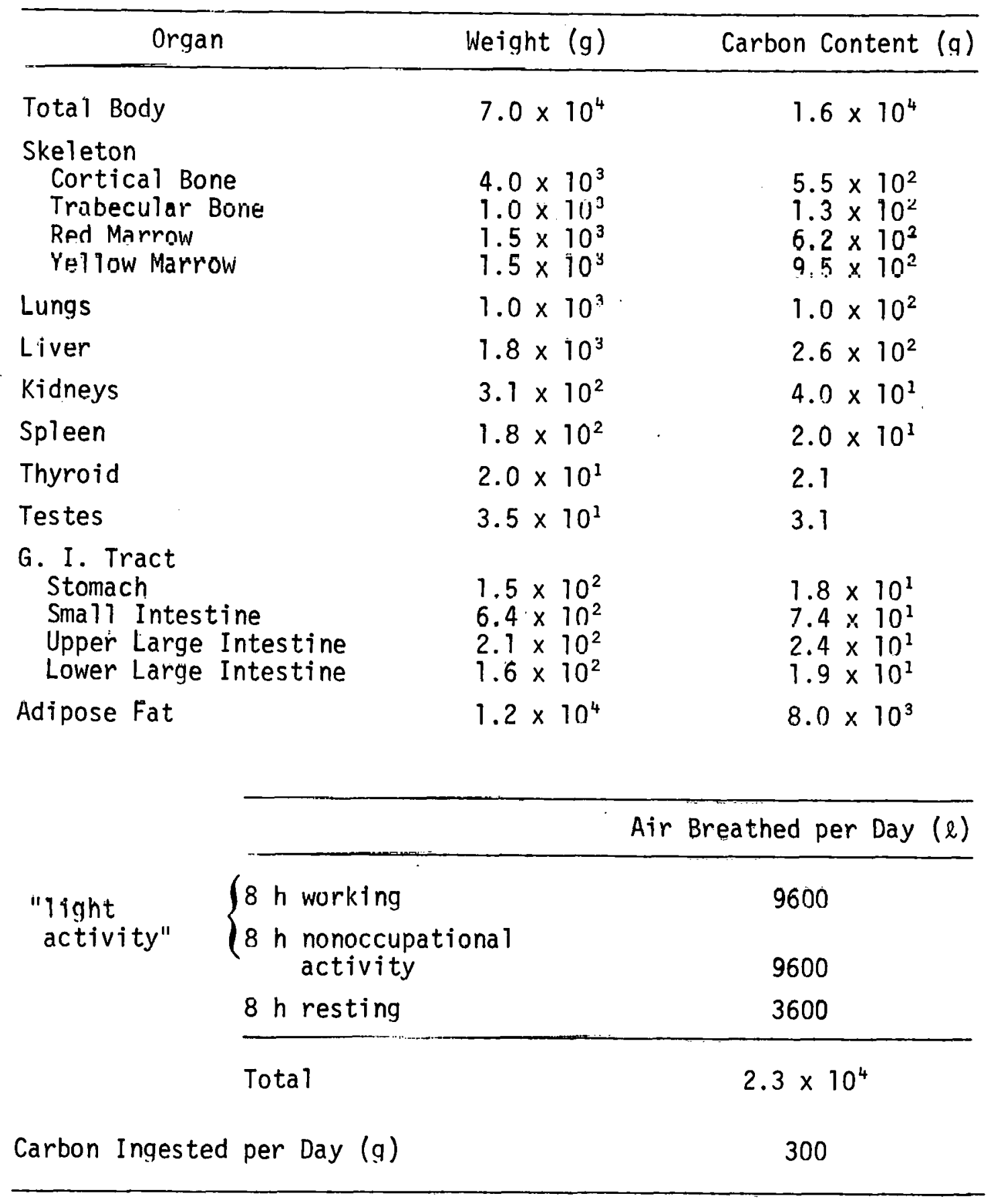




$$
\begin{aligned}
q(t) & =\text { activity burden of the radionuclide in the organ }(\mu C i) ; \\
t & =\text { time (days). }
\end{aligned}
$$

The factor $S$, which depends on the radionuclide and on the mass and geometry of the organ, will be taken as a constant in this discussion. The value of $S$, in the present context, is given by the equation

$$
S=\frac{57.2 \varepsilon}{m}, \mathrm{rem} / \mu \mathrm{Ci}-\mathrm{day}
$$

where

$$
\begin{aligned}
51.2 & =\frac{3.2 \times 10^{9}\left(\frac{\text { dis/day }}{\mu C i}\right) \times 1.6 \times 10^{-6}\left(\frac{\mathrm{erg}}{\mathrm{MeV}}\right)}{\because 100(\mathrm{erg} / \mathrm{g} \text { tissue/rad })} ; \\
\varepsilon & =\text { the effective absorbed energy per disintegration }(\mathrm{MeV} / \mathrm{dis}) \\
\because(\mathrm{rem} / \mathrm{rad}) ; &
\end{aligned}
$$

Carbon-14 is a beta emitter with $\varepsilon=0.05$ (MeV/dis) $(\mathrm{rem} / \mathrm{rad})$. Reference 29 includes in the effective absorbed energy, $\varepsilon$, a relative damage factor $n=5$ when the reference organ is bone; but a different approach to the dosimetry of skeletal tissues will be taken in this report, and accordingly $\varepsilon=0.05 \mathrm{MeV}$ will be used in Eq. (2) for all organs. Thus the dose may be computed from Eq. (1.) by integration:

$$
D(T)=S \int_{0}^{T} q(t) d t
$$

where

$$
\begin{aligned}
D(t)= & \text { dose accumulated by the reference organ between time zero } \\
& \text { and time } T(\mathrm{rcm}) ; \quad \therefore \ldots \\
T & =\text { time at which dose integration ends (days). }
\end{aligned}
$$


The integral on the right of Eq. (3) is the residence ( $\mu \mathrm{Ci}$-days) of the radionuclide in the reference organ.

\subsubsection{Review of metabolic models}

The dynamic quantity $q(t)$ of Eq. (1) depends on the particular history of uptake of the radionuclide by the reference organ and on the organ's metabolic processes with respect to the radionuclide. A model which explicitly incorporates the dynamics of the organ's removal of activity will. be referred to as a "metabolic model" in this discussion.

Recent ICRP documents $28,29,30$ have given metabolic models which represent the reference organ either (1) by a single compartment with firstorder removal and a production (uptake) mechanism which is independent of the compartment's burden of activity or (2) by a combination of two or more such compartments arranged in parallel. In either case, we may speak of a number $M$ of compartments, assumed to satisfy the differential equation

$$
d q_{j} / d t=-\left(\lambda^{r}+\lambda_{j}^{b}\right) q_{j}+f c_{j} I(t)
$$

where

$$
\begin{aligned}
q_{j}(t)= & \text { activity of the radionuclide }(\mu C j) \text { present in the } j \text {-th com- } \\
\lambda^{r}= & \text { radioactive decay constant }\left(d a y^{-1}\right) ; \\
\lambda_{j}^{b}= & \text { metabolic removal rate constant }\left(d a y^{-1}\right) \text { for activity in the } \\
& j \text {-th compartment of the reference organ; } \\
f= & \text { fraction of intake reaching the reference organ; } \\
c_{j}= & \text { fraction of material reaching the reference organ that is }
\end{aligned}
$$




$$
\begin{aligned}
\text { deposited in the } j \text {-th compartment; } \\
I(t)= \\
\text { rate of intake into the body of activity at time } t \\
(\mu \mathrm{C} i / \text { day }) .
\end{aligned}
$$

Reference 29 presents ${ }^{14} \mathrm{C}$ metabolic models for total body, skeleton, and body fat; each such model consists of a single compartment: $(M=1)$. ICRP Publication 10 (Ref. 30) and the extension of this report, 10A (Ref. 31) emphasizes the dependence of the metabolism of ${ }^{14} \mathrm{C}$ upon the particular compound in which it occurs and presents two multiple-compartment models $(M>1)$ for total-body retention, one for ${ }^{14} \mathrm{C}$-labelled bicarbonate and the other for glycine labelled at the $\mathrm{C2}$ position. One compartment of the former model is associated with the skeleton. Bernard ${ }^{32}$ cites experimental data which he interprets as supporting a mean residence time of approximately 40 days for ${ }^{14} \mathrm{C}$ in total body, and he concludes that the ICRP Publication 10 metabolic models need one or more additional long-term compartments to be consistent with such a residence time. Rohwer et al. 31 discuss this point in the context of the uncertainty which it poses for the application of these metabolic models to ${ }^{14} \mathrm{C}$ dose calculations for environmental assessments; they indicate a discrepancy of three orders of magnitude in inhalation doses calculated with retention functions based on these models.

\subsubsection{The specific activity method}

When steady-state concentrations of ${ }^{14} \mathrm{C}$-labelled carbon dioxide may be assumed, metabolic models may be avoided through the use of specific activity calculations. With this approach, it is assumed that the ${ }^{14} \mathrm{C}$. activity per gram of carbon (specific activity) in human tissue approaches 
a steady-state value which is determined by the prevallina specific activity in the air that an individual breathes and in the local atmosphere at each point of production of his dietary inputs. In particular, if a man lives at a geographic point at which the atmospheric specific activity of ${ }^{14} \mathrm{C}$ in stable carbon is constant and if all of his food is produced on site, then the specific activity of his body tissues is assumed to equal the local atmospheric value when equilibrium is achieved. This hypothesis, based on observations of organisms under conditions of constant or slowly-varying atmospheric specific activity, can be challenged with regard to its appropriateness for an exposure environment in which the isotopic ratio experiences narrow-pulse fluctuations of large amplitude. A model of carbon assimilation by plants has been designed to aid in investigating this question in.connection with vegetation grown near the facility, where sporadic occurrences of high ${ }^{14} \mathrm{C}$ concentration create just such an exposure environment. The model is discussed in Secs. 2.2.4, 2.2.5, and 2.2.6. Our approach to the dosimetry for purposes of the present assessment, however, wi 11 be to retain the equilibrium hypothesis, with the understanding that doses computed on this basis might be subject to eventual adjustment by factors which take into account estimates of the specific activity in vegetation produces near the release point. In making conversions from the specific activity of ${ }^{14} \mathrm{C}(\mathrm{Ci} / \mathrm{gC})$ to activity concentration in the air $\left(\mathrm{Ci} / \mathrm{m}^{3}\right)$ it will be assumed throughout this section that ${ }^{12} \mathrm{C}$ is present in the atmosphere in the concentration $0.16 \mathrm{gC} / \mathrm{m}^{3}$. This reference value corresponds to the assumption that airborne carbon is present exclusively as $\mathrm{CO}_{2}$ in the concentration 300 parts per million by volume (STP). 


\subsubsection{Relative contributions of inhalation and ingestion to the dose}

The exposure modes considered are inhalation and ingestion, with associated uptake fractions $f_{a}$ and $f_{w}$, respectively (the factor $f$ in Eq. (4) stands for the appropriate choice of these if uptake is restricted to a single mode). For the simple case of a reference individual whose total diet is produced at the location of his habitation, analysis indicates that at least 99 percent of the steady-state ${ }^{14} \mathrm{C}$ dose rate to an organ is attributable to the ingestion exposure mode. The following argument derives a more general relation, which will be needed again in Sec. 3 .

Suppose the reference individual breathes air at a concentration $Q_{0}$ $\mathrm{Ci} / \mathrm{m}^{3}\left(=Q_{0} \mu \mathrm{Ci} / \mathrm{ml}\right)$. Reference Man breathes $2.3 \times 10^{7} \mathrm{ml}$ of air per day. His uptake rate via inhalation is thus

$$
\left(2.3 \times 10^{7} \mathrm{ml} / \text { day }\right) \times\left(Q_{0} \mu \mathrm{Ci} / \mathrm{ml}\right) \times \mathrm{f}_{\mathrm{a}} \quad \mu \mathrm{Ci} / \text { day } .
$$

Suppose further that his diet is produced at a location where the air concentration of ${ }^{14} \mathrm{C}$ is $Q_{1} \mathrm{Ci} / \mathrm{m}^{3}$. Reference Man ingests $300 \mathrm{~g}$ of carbon per day; therefore, his ingestion uptake rate is

$$
\begin{gathered}
\frac{300 \mathrm{gC} / \text { day }}{0.16 \mathrm{gC} / \mathrm{m}^{3}} \times\left(Q_{1} \mathrm{Ci} / \mathrm{m}^{3}\right) \times\left(10^{6} \mu \mathrm{Ci} / \mathrm{Ci}\right) \times \mathrm{f}_{\mathrm{w}} \\
=1.88 \times 10^{9} \mathrm{Q}_{1} \mathrm{f}_{\mathrm{w}} \quad \mu \mathrm{Ci} / \text { day } .
\end{gathered}
$$

(In practice, $Q_{1}$ will represent a suitable average of air concentrations of ${ }^{14} \mathrm{C}$. at. the various points of production of the reference individual's diet.) The fraction $F$ of the uptake of ${ }^{14} \mathrm{C}$ which is attributable to inhalation is 


$$
F=\frac{2.30 \times 10^{7} \times f_{a} Q_{0} \mu C i / \text { day inhaled }}{\left[2.30 \times 10^{7} f_{a} Q_{0}+1.88 \times 10^{9} f_{w} Q_{1}\right] \mu C i / \text { day total }}
$$

Publication 2 of the ICRP 29 provides values for $f_{a}$ and $f_{w}$ for several organs, but more generally that publication assumes that these fractions are related by the equation

$$
f_{a}=\left(u . b+0.25 / f_{j}\right) f_{w},
$$

where $f_{1}$ is the fraction of the radionuclide passing from the G. I. tract to the blood. This equation is, in fact, based on the lung model for particulate matter, which assumes 25 percent retention of such matter in the lungs and mechanical removal of 50 percent, which is swallowed. This model is inappropriate for $\mathrm{CO}_{2}$ gas, however, and the implied ratio $\mathrm{f}_{a} / \mathrm{f}_{w}=0.75$ $\left(f_{1}=1\right.$ for carbon) is probably conservative: Bernard ${ }^{32}$ makes an argument which would support a value $\mathrm{f}_{\mathrm{a}} / \mathrm{f}_{w} \sim 0.01$ for $\mathrm{CO}_{2}$ gas. Utilization of the conservative value gives

$$
F_{0}=\frac{2.30 \times 10^{7} \times 0.75}{2.30 \times 10^{7} \times 0.75+1.88 \times 10^{9}}=9.09 \times 10^{-3},
$$

while $f_{a} / f_{w}=0.01$ implies $F_{0}=1.22 \times 10^{-4}$. The notation $F_{0}$ has been used to mean the fraction computed from Eq. (5) with $Q_{0}=Q_{1}$. This value is also used to compute the separate contributions, $\dot{D}_{a}$ and $\dot{D}_{w}$, due to inhalation and ingestion, respectively, to the total dose rate $\dot{D}$ when the two exposure modes are associated with different concentrations $Q_{0}$ and $Q_{1}$. We have

$$
\begin{aligned}
& \dot{D}_{a}=F_{0} \text { (DRF) } Q_{0} \text { mrem/yr } \\
& \dot{D}_{w}=\left(1-F_{0}\right)(D R F) Q_{1} \text { mrem } / y r,
\end{aligned}
$$


where (DRF) stands for a dose-rate factor (mrem/yr per $\mathrm{Ci} / \mathrm{m}^{3}$ ) which is calculated for the special case of equal $Q_{0}$ and $Q_{1}$. Such dose-rate factors are given in Table 6 for several reference organs.

The values of $F_{0}$ calculated above indicate that the inhalation exposure mode contributes negligibly to the total dose when inhalation and ingestion are associated with the same atmospheric concentration. When the reference individual breathes air at an elevated concentration, however, the inhalation component can become significant in relation to the total dose if his dietary intake does not rise correspondingly.

\subsubsection{Calculation of dose-rate factors for various internal organs}

If the reference organ is irradiated by sources of activity in other tissues, Eq. (1) must be extended as follows:

$$
\dot{D}_{\text {target+source }}=s_{\text {target+source }} q_{\text {source }} \text { rem/day }
$$

where

$$
\begin{aligned}
\dot{\mathrm{D}}_{\text {tárget+source }}= & \text { component of the dose rate (rem/day) attributed to } \\
& \text { irradiation of the target organ by the activity in } \\
& \text { the source organ; } \\
\mathrm{S}_{\text {target }+ \text { source }=} & \text { dose to target organ per unit residence of the ra- } \\
& \text { dionuclide activity in the source organ (rem } / \mu C i- \\
& \text { day); } \\
= & \text { activity burden of the radionuclide in the source } \\
& \text { organ }(\mu C i) .
\end{aligned}
$$

The total dose rate is then computed by summing Eq. (6) over all source organs. In Eq. (6) the source and target organs may be identical. Quite 
Table 6. Dose Rate Factors for ${ }^{14} \mathrm{C}$ Computed from Snyder et al. ${ }^{34}$.

\begin{tabular}{ll}
\hline Reference Organ & $\begin{array}{l}\text { Dose Rate } \\
\left(\frac{\mathrm{mrem} / \mathrm{yr}}{\mathrm{Ci} / \mathrm{m}^{3}}\right)\end{array}$ \\
\hline $\begin{array}{l}\text { Total Body } \\
\text { Skeleton } \\
\text { Endosteal Cells }\end{array}$ & $1.31 \times 10^{12}$ \\
$\quad$ Red Marrow & $2.08 \times 10^{12}$ \\
Bone & $2.28 \times 10^{12}$ \\
Lung & $8.11 \times 10^{11}$ \\
Liver & $5.75 \times 10^{11}$ \\
Kidneys & $8.30 \times 10^{11}$ \\
Spleen & $7.42 \times 10^{11}$ \\
Thyroid & $6.38 \times 10^{11}$ \\
Testes & $6.03 \times 10^{11}$ \\
G. I. Tract & $5.10 \times 10^{11}$ \\
Adipose Fat & $1.03 \times 10^{12 \mathrm{~b}}$ \\
Skin Dose from Immersion & $3.81 \times 10^{12}$ \\
$\quad$ in Infinite Cloud. & $4.83 \times 10^{8 \mathrm{C}}$ \\
\hline
\end{tabular}

${ }^{a}$ Dilution in 0.16 grams of ${ }^{12} \mathrm{C}$ per cubic meter is assumed ( $300 \mathrm{ppm} \mathrm{CO}_{2}$ by volume).

bose is delivered by contents of lower large. intestine plus ${ }^{14} \mathrm{C}$ content of the wal1. Specific activities in contents and wall were assumed to be equal. The model used to estimate the dose due to the contents was that of Dolphin and Eve. ${ }^{35}$

${ }^{C}$ Computed with the EXREM III code, Trubey and Kaye. ${ }^{36}$ 
often, the only significant contribution to the dose will result from the activity in the target organ itself, but other contributions can be significant.

Dose rate factors are given in Table 6 for a number of reference organs. For all internal organs except the G. I. tract and body fat the dosimetric information provided by Snyder et al. ${ }^{34}$ has been utilized. This reference provides tabulations of factors $S_{\text {target+source }}$ for substitution into Eq. (6). The tabulation covers 60 radionuclides, including ${ }^{14} \mathrm{C}$, and for each nuclide, $S$ factors for 22 source and 24 target tissues are given. These factors were computed for an anthropomorphic phantom with biological and physiological parameters which closely approximate corresponding values for the ICRP's Reference Man. ${ }^{28}$ In the internal dose calculations for" Table 6, the source and target organs are identical except for skeletal tissues, in which the dose rates for endosteal cells and red marrow include components of irradiation by bone and marrow. The $S$ factors were not used in the calculation of dose rates to body fat and the G. I. tract; the methods applied to these tissues are discussed in Secs. 1.3.6.3 and 1.3.6.2, respectively.

The dose rate factors in Table 6 for total body, lung, liver, kidneys, spleen, thyroid, and testes were calculated by the following method. Let $Q$ denote the local activity concentration of ${ }^{14} \mathrm{C}$ in the air $\left(\mathrm{Ci} / \mathrm{m}^{3}\right)$. If one assumes dilution in 0.16 grams of stable carbon per cubic meter of air, the ${ }^{14} \mathrm{C}$ activity per gram of carbon is

$$
Q /(0.16+0.223 Q) \cdot \mathrm{Ci} / \mathrm{g} \mathrm{C} \text {; }
$$


where $0.223=\mathrm{g} \mathrm{C} / \mathrm{Ci}^{14} \mathrm{C}$. Except at very high concentrations $\left(0.2230>\sim 10^{-2}\right)$, the approximation $Q / 0.16 \mathrm{Ci} / \mathrm{g} \mathrm{C}$ may be used. If an organ of man is in steady-state equilibrium with this atmospheric specific activity, its burden $q(\mu \mathrm{C} i)$ of ${ }^{14} \mathrm{C}$ is given by

$$
q=10^{6} M_{C} Q / 0.16=\left(6.25 \times 10^{6}\right) M_{C} 0 \mu C i
$$

where $10^{6}=\mu \mathrm{Ci} / \mathrm{Ci}$ and $M_{C}=$ grams of carbon in the organ. The dose rate $\dot{\mathrm{D}}$ (mrem/yr) is [from Eq. (1)]

$$
\begin{aligned}
\dot{D} & =S q\left(3.65 \times 10^{5}\right) \mathrm{mrem} / \mathrm{yr} \\
& =\left(2.28 \times 10^{12}\right) \mathrm{M}_{\mathrm{C}} Q \mathrm{~S} \mathrm{mrem} / \mathrm{yr}
\end{aligned}
$$

where $3.65 \times 10^{5}$ converts from $\mathrm{rem} / \mathrm{day}$ to $\mathrm{mrem} / \mathrm{yr}$. With $0=1 \mathrm{ci} / \mathrm{m}^{3}$ this formula has been applied to the calculation of those dose-rate factors listed above.

\subsubsection{Skeletal tissues}

ICRP Publication $11^{37}$ has suggested a more detailed approach to the dosimetry of skeletal tissues than was advocated in Ref. 29. Reference 37 notes the identification of endosteal osteogentc t1ssues and red mar row as possible tissues at risk with respect to radiation-related bone tumor and leukemia, respectively. These tissues receive significant components of their doses from other skeletal tissues. With the appropriate $S$ factors of Snyder et al., ${ }^{34} \mathrm{Eq}$. (7) is applied to each source tissue individually and the partial contributions summed to give the total dose rate. The following table summarizes the source-target relationships: 


$\begin{array}{ccc}\text { Cortical Cancellous } & \text { Red } & \text { Yellow } \\ \text { Bone } & \text { Bone } & \text { Marrow Marrow }\end{array}$

Target Organ

\begin{tabular}{|c|c|c|c|}
\hline Bone & $x$ & $x$ & $X$ \\
\hline Red Marrow & $x$ & $X$ & $x$ \\
\hline Endosteal Cells & $x$ & $x$ & $x$ \\
\hline
\end{tabular}

\subsubsection{Body fat}

Body fat is not included as a reference tissue by snyder et al. 34 because of the difficulty of mathematically defining a mass with indefinite boundaries for the purpose of making Monte Carlo calculations: In Publication 2 of the ICRP, 29 however, body fat is defined as a reference tissue and from a dosimetric point of view becomes the critical organ for ${ }^{14} \mathrm{C}$. Reference Man's adipose fat weighs $12 \mathrm{~kg}$, of which approximately 8 $\mathrm{kg}$ is carbon. Equation (7) may be used to estimate the dose-rate factor, with $Q=1$ and $S$ computed from Eq. (2).

\subsubsection{Gastrointestinal tract}

The G. I. tract presents a special problem, in that its segments are irradiated not only by the ${ }^{14} \mathrm{C}$ in their tissues but also by their migrating contents. Thus two components of the dose to each segment had to be computed from Eq. (7) with Eq. (2) substituted for $S$ and $m$ standing for the mass in grams of the segment. The second required a dynamic model of mass transport and mass and activity absorption from the gut. For this purpose, the model proposed by. Do:Tphin and Eve ${ }^{35}$ was chosen; 95 percent activity absorption in the small intestine was assumed, with no activity absorption in the other segments. The following table shows, for each segment of 
the G. I. tract, the dose-rate factor for each of the two components of the dose. The lower large intestine is seen to receive the largest dose.

\begin{tabular}{llll} 
& \multicolumn{3}{c}{ Dose Rate $\left(\frac{\mathrm{mrem} / \mathrm{yr}}{\mathrm{C} i / \mathrm{m}^{3}}\right)$} \\
\cline { 2 - 5 } Segment & Contents & ${ }^{14} \mathrm{C}$ in Tissue & Tota1 \\
\hline Stomach & $1.57 \times 10^{11}$ & $7.01 \times 10^{11}$ & $8.58 \times 10^{11}$ \\
Smal1 intest1ne & $9.99 \times 10^{10}$ & $6.75 \times 10^{11}$ & $7.75 \times 10^{11}$ \\
Upper large intestine & $1.70 \times 10^{11}$ & $6.67 \times 10^{11}$ & $8.37 \times 10^{11}$ \\
Lower large intestine & $3.33 \times 10^{11}$ & $6.94 \times 10^{11}$ & $1.03 \times 10^{12}$
\end{tabular}

\subsubsection{External dose}

The EXREM III ${ }^{36}$ computer code was used to compute an estimate of the extermal dose rate at the skin surface which would result from immersion in an infinite cloud of ${ }^{14} \mathrm{CO}_{2}$. From this infurilltion, the dosc-rate factor $4.83 \times 10^{8} \mathrm{mrem} / \mathrm{yr}$ per $\mathrm{Ci} / \mathrm{m}^{3}$. (Table 2) was derived. It is assumed that no significant skin penetration by the $50 \mathrm{keV}$ beta particles will occur.

\subsection{PREDICTIONS OF ${ }^{14}$ C TRANSPORT AND CYCLING IN A MODEL ECOSYSTEM BORDERING A HTGR REPROCESSING FACILITY}

This section discusses the hypothesized rates of release of ${ }^{14} \mathrm{C}$ from the model HTGR fuel reprocessing facility, the atmospheric dispersion model and meteorology which were used to estimate time-averaged concentrations' of ${ }^{14} \mathrm{C}$ at ground level at various points within 50 miles of the facility, and the plant carbon assimilation modeling which was applied to the estimation of the ${ }^{14} \mathrm{C}$ specific activity in vegetation near the facility 
in response to the sporadic nature of the resultant ground level concentrations. The atmospheric dispersion model and the dosimetric information presented in Sec. 1.3 constitute the basis for the estimation of radiation doses to an individual at the facility's boundary and to a population in the region.

\subsection{Source Term}

Only the routine continuous release situation was considered for analysis in this report. All ${ }^{14} \mathrm{C}$ effluents from the reprocessing facility were assumed to be released to the atmosphere through a tall stack as carbon dioxide gas; because of this assumed mode of release, no accidental releases or releases to surface waters were hypothesized. The assumed release rate used for transport and dosimetry evaluations was 5,000 Ci/yr $=1.59 \times 10^{-4} \mathrm{Ci} / \mathrm{sec}$.

\subsection{Carbon-14 Transport Calculations}

The atmospheric transport of ${ }^{14} \mathrm{C}$ as a gaseous effluent from a HTGR fuel reprocessing plant was calculated using meteorological data for the Oak Ridge area. It should be emphasized that these data were used for this analysis because of their immediate availability in the kind of detail that was needed; it is not suggested that the 0ak Ridge area is representative of a modal set of meteorological conditions.,

\subsubsection{The Atmospheric Transport Model}

The Atmospheric Transport Model (ATM) of Mills and Reeves ${ }^{38}$ based on the Gaussian plume model (Gifford ${ }^{39}$ ) formed the basis of the atmospheric transport calculations. The version described in the original publication 
uses time averaged climatological data and averages concentrations over each $22.5^{\circ}$ compass sector.

\subsubsection{Hourly version of the Atmospheric Transport Model}

A special modification of the ATM was prepared to predict short-term average concentrations resulting from a specified stability class, wind speed, and wind direction. In this version of the ATM, wind direction, wind speed, and stability class are considered fixed, and the ground-level concentration is calculated as a function of downwind distance. Such a fixed set of conditions might last for approximately one hour. Thus by running this modified version of the model for all the significant speed and stability conditions associated with the prevalent wind direction, one can construct an hour by hour concentration history which would be typical of points in the direction of the prevalent wind vector (throughout the growing season, for example).

\subsubsection{Atmospheric data}

Speed-stability wind rose data for the Oak Ridge area were obtained from TVA. The data are monthly averages and these were used in the cl1matological model. We have found from an analysis of TVA data that the important stability classes are $A, D, E$ and $F$ for the 0ak Ridge area. With respect to plant uptake of ${ }^{14} \mathrm{C}$, stability class $A$ (very unstable) is quite important because it results in high concentrations at close distances. Since photosynthetic incorporation of ${ }^{14} \mathrm{C}$ occurs only during the daytime, it is important to identify the frequency of daytime class A stability. 


\subsubsection{Plume rise}

Two different reprocessing. plant designs were studied which have different stack heights and different parameters for the exiting gases (Table 7).

The first case is represented by a present generation plant design with a $300 \mathrm{ft}$ stack and exit gases assumed to be at ambient temperature. There is a smail amount of momentum rise associated with this gas. We have followed the procedure of Briggs 40 and have used the most conservative estimate of plume rise in all cases.

The second case is represented by a future generation of plant using a $1000 \mathrm{ft}$ stack with exit gases at $80^{\circ} \mathrm{C}$. The higher stack and elevated off-gas temperature gives a plume rise which is quite dependent on wind speed and atmospheric stability. However, for low wind speeds the parameters for the future generation plant can more than double the effective stack height (Briggs ${ }^{40}$ ). The ATM uses the Briggs formulation and calculates plume rise according to the prevailing meteorological parameters.

For buoyant plumes and the greater stack height, the increase in effective source height reduces close-in ground level concentration values substantially. These relationships are illustrated in Fig. 2, which shows the effective height increment obtained as a function of the temperature difference between the stack gas and the surrounding air; and Fig. 3, which shows the maximum ground level concentration as a function of effective source height.

\subsubsection{Dispersion parameters}

The best-known dispersion parameters are those generally referred to as the Pasquill-Gifford ones. These parameters were not intended 
Table 7. Stack parameters used to calculate atmospheric dispersion of ${ }^{14} \mathrm{C}$ released from a model HTGR fuel reprocessing plant.

\begin{tabular}{lcc}
\hline & Present Generation & Future Generation \\
\hline Stack Height & $300 \mathrm{ft}$ & $1000 \mathrm{ft}$ \\
$\begin{array}{l}\text { Heat Output in Stack } \\
\text { Gases }\end{array}$ & $\begin{array}{c}\text { Zero } \\
\text { Stack Ejection Velocity }\end{array}$ & $0.42 \times 10^{8} \mathrm{Btu} / \mathrm{hr}$ \\
$\begin{array}{l}\text { Internal Diameter of } \\
\text { Stack }\end{array}$ & $44 \mathrm{ft} / \mathrm{sec}(\mathrm{STP})$ & $50 \mathrm{ft} / \mathrm{sec}(\mathrm{STP})$ \\
$\begin{array}{l}\text { Stack Gas Temperature } \\
\text { Stack }\end{array}$ & $4.92 \mathrm{ft}$ & $11.92 \mathrm{ft}$ \\
\hline
\end{tabular}




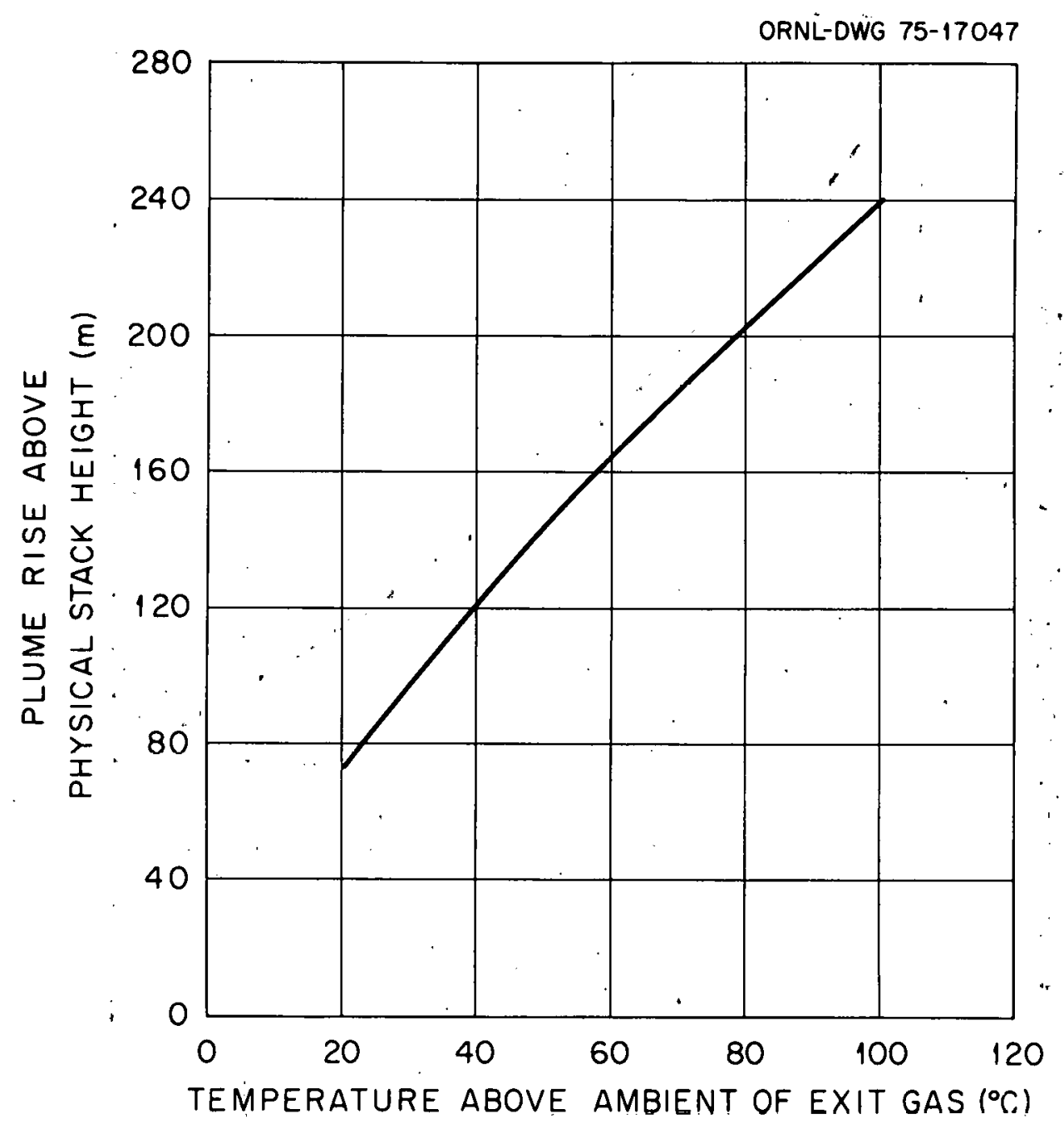

Fig. 2. Increase in effective height of stack as 'a function of exit gas' temperature (wiind speed $=1 \mathrm{~m} / \mathrm{sec}$ ). 


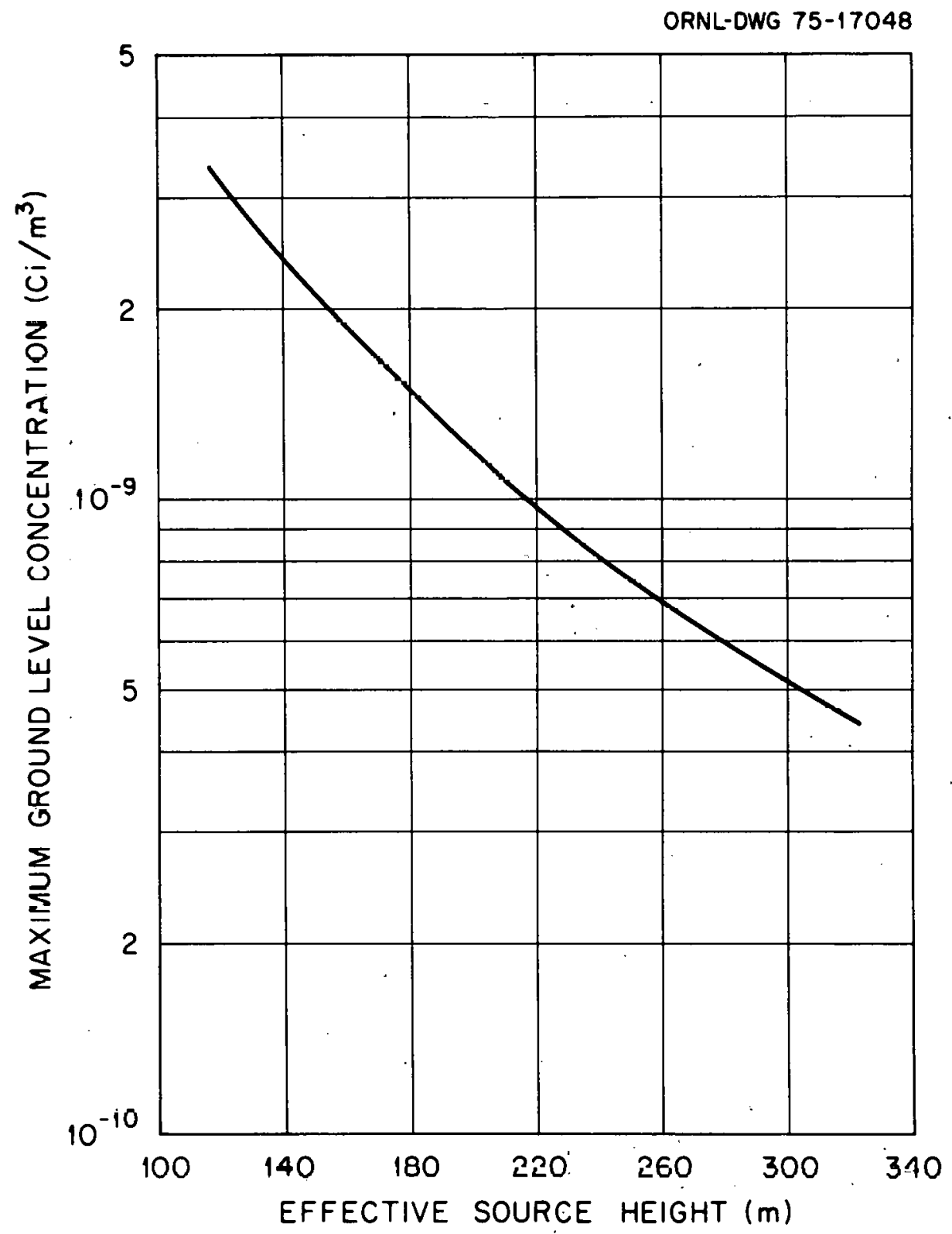

Fig. 3. Maximum ground level concentration as a function of effective source height (Class A stability, wind speed $=1 \mathrm{~m} / \mathrm{sec}$ ). 
originally for use at distances greater than approximately ten kilometers. They are, however, frequently used at greater distances. Recently, some investigators have constructed dispersion parameters which are valid at greater distances. Hosker ${ }^{41}$ describes the more recent dispersion parameters and we have followed his procedures in choosing our parameters.

\subsubsection{Wind stability and speed classes}

Local temperature profile data obtained by TVA and classified by atmospheric stability (U.S.A.E.C. Regulatory Guide 1.21, Revision 1, June 1974) supplied the necessary climatological input to the air model. In this scheme there are seven stability classes ranging from 1 (extremely unstable) to 7 (extremely stable) with number 4 corresponding to neutral conditions. These correspond in essence to the Pasquill-Gifford classes A through $F$. In using the ATM for Oak Ridge area stability data, we have consolidated the two most stable classes. An important fact which is evident in the TVA data is that the very unstable condition (PasquillGifford Class A) is quite prevalent in the Oak Ridge area during the warmer months. This condition will be responsible for much of the elevated ${ }^{14} \mathrm{C}$ concentration in those areas near the plant.

The TVA data used the following values to typify six wind speed classes:

$\begin{array}{cc}\text { Class } & \text { Wind Speed }(\mathrm{m} / \mathrm{sec}) \\ & 0.9 \\ 2 & 2.4 \\ 3 & 4.4 \\ 4 & 6.9 \\ 5 & 9.5 \quad \\ 6 & 14.0\end{array}$




\subsubsection{Basis for calculating time averages}

The data set resulting from TVA measurements in the Oak Ridge area was in the form of a speed-stability wind rose on a monthly basis, and contained the relative frequency of occurrence of a given stability class together with a given wind speed class and the compass sector from which the wind blows. The ATM sums the contributions from all relevant events in proportion to the freyueicicies with which thcy occur to calculate a time-averaged concentration at a specified point.

\subsubsection{Calculation of exposure history on an hour by hour basis}

An analysis of the stability-speed wind rose allowed the identification of the most prevalent wind speed-stability combinations which occur in the Oak Ridge area. Calculation of ground level concentration along the wind vector yielded maximum concentrations for these conditions. Further analysis of the wind rose data identffied the wind direction associated most frequently with these occurrences. The resulting ground level concentrations were combined with the frequency of occurrence of the relevant wind direction. For a given location, the occurrences of high level concentrations of ${ }^{14} \mathrm{CO}_{2}$ associated with the set of wind speedstability combinations will be termed plume events. By using a Monte Carlo technique, hour by hour plume events could be generated for a typical growing season; these plume events were used to drive the Carbon Assimilation Model (CAM).

The most frequently occurring stability classes in the Oak Ridge area were Pasquil1-Gifford Classes $A, D, E$, and $F$. Wind speed classes 
$1,2,3$, and 4 were important, although al1 speed classes were not important for all stability classes. Most frequently the wind was from the Southwest. We have analyzed conditions which refer to the case of a southwesterly wind having the stability and speed characteristics noted above. Such a combination would be expected to yield the maximum opportunity for assimilation of ${ }^{14} \mathrm{C}$ in growing plants. Because of different plume rise characteristics the concentration pattern downwind of the stack was significantly different for the two types of plant design. An example of an important meteorological condition which illustrates this difference is given in Fig. 4, which shows the centerline plume ground concentration for the A stability class and wind speed class 1 in the case of both designs.

\subsubsection{Diurnal pattern of stability classes}

The meteorological data represented the frequency of occurrence of the six stability classes together with wind speed and wind direction. These data represent the fractions of the time during the month which are associated with the respective conditions. The recognition that some stability conditions are daytime and some nocturnal can help to extend the usefulness of these meteorological data.

In calculating ground level concentrations for input to the Carbon Assimilation Model the diurnal character of the wind stability classes was taken into account. Stability classes A, B, and C can be considered to be daylight occurrences, whereas classes $E$ and $F$ are nocturna $7^{42}$; class D was equally apportioned between daylight and nighttime hours.

Thus in estimating ground level concentration histories of ${ }^{14} \mathrm{CO}_{2}$ during 


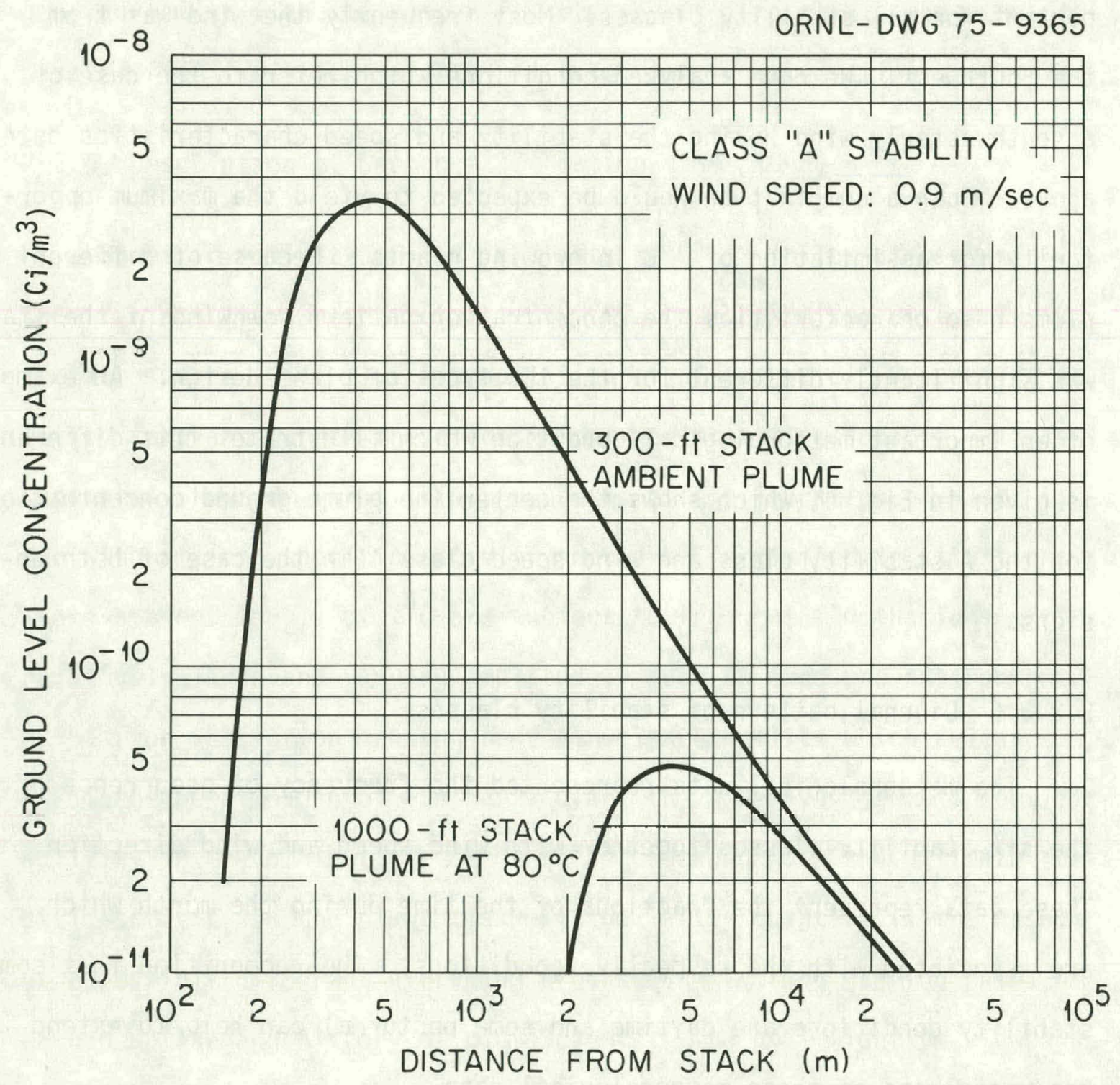

「ig. 4. Plume centerline concentration for the two HTGR fuel reprocessing plant designs as described in Table 7 . The atmospheric conditions are those which produce high concentrations near the stack, and the advantages of a high stack and heated plume are demonstrated. 
daylight hours (i.e., when photosynthesis is taking place), one should choose those meteorological conditions which are primarily daytime in character. It follows that the a priori monthly probabilities should be adjusted accordingly for daylight hours.

The climatology of a location, as reflected in the frequency of occurrence of the various stability classes, can have a marked effect on close-by ground level concentrations. This effect can be appreciated when one notes that for the 300-ft stack (see Fig. 4) the maximum ground level concentration occurs at less than $1 \mathrm{~km}$ from the source for an $A$ stability condition; for a $D$ condition, it is found to occur at a point between 1.5 and $2.0 \mathrm{~km}$ from the source and to be 4 to 5 times lower. The climatology of Oak Ridge, Tennessee, shows much class A stability throughout the summer months (about 20\%) and will therefore lead to increased concentrations at nearby locations. A site such as Springfield, Illinois, shows much less evidence of class A stability, and preliminary estimates indicate a corresponding decrease in the average seasonal concentration by an approximate factor of 5 .

It is of interest to compare our predicted concentrations with those of other investigators whenever such comparisons are possible. One oppor-. tunity is provided by a recent study based on 0ak Ridge area meteorology. Using meteorological data compiled by the U. S. Weather Bureau at Oak Ridge, Binford et al. ${ }^{43}$ calculated an annual $X / Q$ of $1.72 \times 10^{-7} \mathrm{sec} / \mathrm{m}^{3}$ for a point 2.1 miles NE of stack 7911 on the Oak Ridge Reservation; this value is based on an effective stack height of 80.8 meters with no com-. pensation for plume rise due to higher-than-ambient exit gas temperatures. Our corresponding $X / Q$ for the 100-meter stack (effective stack height 
117 meters) at a point 2.9 miles NE is $1.12 \times 10^{-7} \mathrm{sec} / \mathrm{m}^{3}$, which is in good agreement with the number reported by Binford et al. when the disparate effective stack heights are taken into consideration.

\subsubsection{Description of Carbon Assimilation Model (CAM)}

Specific activity of ${ }^{14} \mathrm{C}$ in plants tends to follow atmospheric ${ }^{14} \mathrm{C}$ specific activity where the ambient ${ }^{14} \mathrm{CO}_{2}$ has been mixed uniformly in the atmosphere (Fig. 1). Extrapolation of atmospheric ${ }^{14} \mathrm{C}$ specific activity to plants under these conditions would seem reasonable. It is suggested, however, that this hypothesis of equilibration of plant tissue with ambient specific activity should be reexamined in situations where ambient levels of ${ }^{14} \mathrm{C}$ are subject to frequent fluctuations of relatively large and varying amplitude. Such an exposure environment exists for vegetation growing near a nuclear facility which releases ${ }^{14} \mathrm{C}$ into the atmosphere. In particular, the time-averaged ${ }^{14} \mathrm{C}$ specific activity in the ambient air needs to be compared with the ultimate specific activity in the plant tissues; the latter quantity is the result of a possibly different averaging process, reflecting varying rates of carbon uptake and history of plume events. The goal might be viewed as the estimation of a ratio $S_{p} / \bar{S}_{a}$, where $S_{p}$ denotes the specific activity in a plant's tissue and $\bar{S}_{a}$ stands for the time-averaged ambient atmospheric specific activity for the growing season, restricted to daylight hours. If the value of this ratio at the end of the growing season is viewed as a transfer factor, with respect to ${ }^{14} \mathrm{C}$ in man's food chain, then a value larger than unity would suggest an amplification effect, whereas a value of one is compatible with the equilibrium hypothesis; 
a value less than one would indicate an apparent attenuation. Such a quantity is in no way intended to suggest a departure from mass conservation or an unusual isotopic discrimination; it should be thought of, rather, as a means of adjusting the more conveniently calculated ambient time average to take into account the varying exposure environment and metabolic factors of the plant.

In this section, we describe the plant growth Carbon Assimilation Model (CAM), which was designed to facilitate the study of the specific activity in the plant as it responds to plume events of high ambient concentration of ${ }^{14} \mathrm{C}$ similar to those that would occur near a fuel reprocessing plant. A listing of the model's computer implementation, together with a table of the principal program variables and their symbolic counterparts from the mathematical forumulation, is given in the Appendix.

The CAM is a model of plant carbon dynamics representing a hypothetical vegetable crop species based on the plant growth model of Dixon ${ }^{44}$. The CAM is modified to operate on an hourly time scale and simulates the dynamics of hoth ${ }^{14} \mathrm{C}$. and ${ }^{12} \mathrm{C}$.

A description of the general form of the plant carbon dynamics model is followed by a more detailed description of the plant growth model which assimilates ${ }^{14} \mathrm{C}$.

The carbon dynamics are considered separately for roots, leaves and stems since these variables are included in several process models. We consider here only the carbon dynamics of leaves, which receive the greatest proportion of photosynthate. Operationally there are two sets of equations, one set for ${ }^{14} \mathrm{C}$ and a second set for ${ }^{12} \mathrm{C}$. For each plant 
40

component, the total carbon pool is the sum of ${ }^{14} \mathrm{C}$ and ${ }^{12} \mathrm{C}$. The leaf carbon mass balance equations are

$$
{ }^{14} \dot{C}_{L}={ }^{14} G_{L}-{ }^{14} M_{L}-{ }^{14} R_{L}
$$

$$
\begin{aligned}
& \text { for }{ }^{14} \mathrm{C} \text {, and } \\
& \qquad{ }^{12} \dot{C}_{\mathrm{L}}={ }^{12} \mathrm{G}_{\mathrm{G}}-{ }^{12} \mathrm{M}_{\mathrm{L}}-{ }^{12} \mathrm{R}_{\mathrm{L}}
\end{aligned}
$$

for ${ }^{12} \mathrm{C}$, where

$$
\begin{aligned}
& { }^{14} \dot{C}_{\mathrm{L}}=\text { mass balance rate of }{ }^{14} \mathrm{C} \text { in leaves }\left(\mathrm{g} \mathrm{m}^{-2} \mathrm{hr}-1\right) \\
& { }^{12} \dot{C}_{\mathrm{L}}=\text { mass balance rate of }{ }^{12} \mathrm{C} \text { in leaves }\left(\mathrm{g} \mathrm{m}^{-2} \mathrm{hr}-1\right) \text {, } \\
& { }^{14} \mathrm{G}_{\mathrm{L}}=\text { growth rate of }{ }^{14} \mathrm{C} \text { in leaves }\left(\mathrm{g} \mathrm{m}^{-2} \mathrm{hr}^{-1}\right) \text {, } \\
& { }^{12} \mathrm{G}_{\mathrm{L}}=\text { growth rate of }{ }^{12} \mathrm{C} \text { in leaves }\left(\mathrm{g} \mathrm{m}^{-2} \mathrm{hr}^{-1}\right) \text {, } \\
& { }^{14} \mathrm{M}_{\mathrm{L}}=\text { mortality rate of }{ }^{14} \mathrm{C} \text { inleaves }\left(\mathrm{g} \mathrm{m}^{-2} \mathrm{hr}-1\right) \text {, } \\
& { }^{12} \mathrm{M}_{\mathrm{L}}=\text { mortality rate of }{ }^{12} \mathrm{C} \text { in leaves }\left(\mathrm{g} \mathrm{m}^{-2} \mathrm{hr}^{-1}\right) \text {, } \\
& { }^{14} \mathrm{R}_{\mathrm{L}}=\text { respiration rate of }{ }^{14} \mathrm{C} \text { in leaves }\left(\mathrm{g} \mathrm{m}^{-2} \mathrm{hr}-1\right) \text {, } \\
& { }^{12} \mathrm{R}_{\mathrm{L}}=\text { respiration rate of }{ }^{12} \mathrm{C} \text { in leaves }\left(\mathrm{g} \mathrm{m}^{-2} \mathrm{hr}-1\right) \text {. }
\end{aligned}
$$

Total leaf carbon then is expressed as

$$
c_{T L}=\int{ }^{14} \dot{C}_{L} d t=\int{ }^{12} \dot{C}_{L} d t
$$

where

$$
C_{T L}=\text { total leaf carbon }\left(\mathrm{g} / \mathrm{m}^{2}\right)
$$




$$
\begin{aligned}
& { }^{14} C_{L}={ }^{14} C \text { in leaves }\left(\mathrm{g} / \mathrm{m}^{2}\right) \\
& { }^{12} C_{L}={ }^{12} C \text { in leaves }\left(\mathrm{g} / \mathrm{m}^{2}\right)
\end{aligned}
$$

The set of equations for each form of carbon is solved numerically with the Runge-Kutta integration method using the Continuous System Modeling Program (CSMP III) simulation language ${ }^{45}$. The state variable of primary interest is the specific activity of ${ }^{14} C$ in plant leaves $\left(S_{p}\right)$ which is calculated as $4.46 \mathrm{Ci} / \mathrm{g}{ }^{14} \mathrm{C} \times\left({ }^{14} \mathrm{C}_{\mathrm{L}} / \mathrm{C}_{\mathrm{TL}}\right)$.

\subsubsection{Plant growth rate}

The expression for photosynthesis in the plant growth model is based on an analagous equation for a gaseous diffusion system (Penman and Schofield ${ }^{46}$ ):

$$
\text { net flux }=\frac{\mathrm{CO}_{2} \text { concentration gradient }}{\text { transfer resistance }}
$$

In terms of the model, the net volume flux of $\mathrm{CO}_{2}$ exchange $\left(\mathrm{cm}^{3} \mathrm{~cm}^{-2} \mathrm{~s}^{-1}\right)$ is

$$
F_{v}=\frac{\mathrm{CO}_{2 a}-\mathrm{CO}_{2 c}}{r_{\mathrm{CO}_{2}}} \text {, }
$$

where

$$
\begin{aligned}
& \mathrm{CO}_{2 \mathrm{a}} \text { - ambient } \mathrm{CO}_{2} \text { concentration }\left(\mathrm{cm}^{3} / \mathrm{cm}^{3}\right), \\
& \mathrm{CO}_{2 \mathrm{c}}=\mathrm{CO}_{2} \text { concentration at chloroplast surface }\left(\mathrm{cm}^{3} / \mathrm{cm}^{3}\right) \text {, and } \\
& \mathrm{r}_{\mathrm{CO}_{2}}=\text { total } \mathrm{CO}_{2} \text { transfer resistance }(\mathrm{s} / \mathrm{cm}) .
\end{aligned}
$$


The total $\mathrm{CO}_{2}$ transfer resistance consists of separate resistance terms for stomatal resistance and internal leaf resistance. Of the two, stomatal resistance normally dominates:

$$
r_{\mathrm{CO}_{2}}=r_{\mathrm{s}}+r_{i}
$$

where $r_{s}$ is stomatal resistance and $r_{\mathfrak{i}}$ is internal leaf resistance. The latter quantity is written as a function of temperature and light intensity.

$$
r_{i}=P_{1} e^{-b_{1} T} \cdot e^{-b_{2} I x}+P_{5}
$$

where

$$
\begin{aligned}
& \mathrm{P}_{1}=\text { maximum resistance }(\mathrm{s} / \mathrm{cm}) \\
& T=\text { average hourly temperature }\left({ }^{\circ} \mathrm{C}\right) \\
& I_{X}=\text { average } 1 \text { ight intensity in the canopy }\left(\mathrm{cal} \mathrm{cm}^{-2} \mathrm{~min}^{-1}\right) \\
& \mathrm{P}_{5}=\text { minimum resistance }(\mathrm{s} / \mathrm{cm})
\end{aligned}
$$

and $b_{1}$ and $b_{2}$ are constants. The average light intensity in the canopy is a function of leaf area index:

$$
I x=I 0 e^{-k \cdot L A I}
$$

where

$$
\begin{aligned}
& \text { Io - the light intensity abnve the rannny } \\
& k \text { = attenuation constant } \\
& \text { LAI = leaf area index }\left(\mathrm{m}^{2} / \mathrm{m}^{2}\right)
\end{aligned}
$$

Leaf area index (LAI) is a dynamic function of total leaf carbon $\left(C_{T L}\right)$ and an empirical ratio of leaf area to leaf weight: 


$$
\frac{d}{d t}(L A I)=\left[\begin{array}{lll}
\frac{d}{d t} & \left(f_{10} \cdot C_{T L}\right)
\end{array}\right]\left[1-\frac{(L A I)}{(L A I)_{\max }}\right]
$$

where

$$
\begin{aligned}
& f_{10}=\text { leaf area to leaf weight ratio }\left(\mathrm{m}^{2} / \mathrm{g}\right), \\
& \mathrm{C}_{\mathrm{TL}}=\text { total leaf carbon, and } \\
& \mathrm{LAI}_{\max }=\text { maximum leaf area index }\left(\mathrm{m}^{2} / \mathrm{m}^{2}\right) .
\end{aligned}
$$

The function $f_{10}$ is a cubic polynonial function of time fitted to the empirical data of Hughes ${ }^{47}$. The total net volume flux can be expressed as independent fluxes of ${ }^{14} \mathrm{C}$ and ${ }^{12} \mathrm{C}$ :

$$
\begin{aligned}
F_{v} & =\left[\left({ }^{12} \mathrm{CO}_{2 \mathrm{a}}-{ }^{12} \mathrm{CO}_{2 \mathrm{c}}\right)+\left({ }^{14} \mathrm{CO}_{2 \mathrm{a}}-{ }^{14} \mathrm{CO}_{2 \mathrm{c}}\right)\right] / \mathrm{r}_{\mathrm{CO}} \\
& ={ }^{12} \mathrm{~F}_{\mathrm{v}}+{ }^{14} \mathrm{~F}_{\mathrm{v}}
\end{aligned}
$$

The ambient $\mathrm{CO}_{2}$ concentration is estimated to be $3.4 \times 10^{-4} \mathrm{~cm}^{3} \mathrm{~cm}^{-3}$ at the time of the HTGR fuel economy from the model of Bolin and Eriksson ${ }^{48}$. The calculation of ground-level ${ }^{14} \mathrm{CO}_{2}$ concentrations was presented in Sec. 2.2.3.5 and the incorporation of these data in the plant growth model is described in Sec. 2.2.5. The ${ }^{12} \mathrm{CO}_{2}$. concentration at the leaf chloroplast is written as an empirical function of temperature (Wuenscher and Kozlowski ${ }^{49}$ ):

$$
{ }^{12} \mathrm{CO}_{2 \mathrm{C}}=\left\{\begin{array}{cc}
2.5 \times 10^{-4}-8.33 \times 10^{-6}(\mathrm{~T}-20) \mathrm{T} \geq 20 \\
2.5 \times 10^{-4} & \mathrm{~T}<20
\end{array}\right.
$$

where $T$ is the average hourly temperature. 
Concentrations of ${ }^{14} \mathrm{CO}_{2}$ at the chloroplast during a non-plume event are assumed to be proportional to the normal ambient concentrations of ${ }^{14} \mathrm{CO}_{2}$. These values of ${ }^{14} \mathrm{CO}_{2 \mathrm{c}}$ are calculated by multiplying ${ }^{12} \mathrm{CO}_{2 \mathrm{c}}$ by the pre-1950 ${ }^{14} \mathrm{C}$ to total sarbon ratio of $1.41 \times 10^{-2}$ times a $30 \%$ increase from residual ${ }^{14} \mathrm{C}$ due to bomb testing (Fairhall and Young ${ }^{5}$ ). During a plume event, the ${ }^{14} \mathrm{C}$ concentration at the chloroplast is less certain. We make the assumption of an instantaneous build-up of ${ }^{14} \mathrm{CO}_{2}$ at the chloroplast proportional to the ambient ${ }^{14} \mathrm{CO}_{2}$ concentration during a plume event:

$$
{ }^{14} \mathrm{CO}_{2 \mathrm{c}}={ }^{12} \mathrm{CO}_{2 \mathrm{c}} \cdot{ }^{14} \mathrm{CO}_{2 \mathrm{a}}{ }^{12} \mathrm{CO}_{2 \mathrm{a}}
$$

The net mass flux of carbon exchange in $\mathrm{gC} \mathrm{cm}^{-2} \mathrm{hr}^{-1}$ is calculated from the net volume flux of $\mathrm{CO}_{2}$ exchange by multiplying by a set of coefficients:

$$
n_{F_{\mathrm{In}}}={ }^{n_{F}} \cdot \rho \cdot 3.6 \times 10^{3}
$$

where

$$
\begin{aligned}
& n_{F_{v}}=\text { net volume flux }\left(\mathrm{cm}^{3} \cdot \mathrm{cm}^{-2} \cdot \mathrm{s}^{-1}\right), \\
& \rho \quad=\text { density of pure } \mathrm{CO}_{2} \text { at ambient temperature and pressure }\left(\mathrm{g} / \mathrm{cm}^{3}\right) .
\end{aligned}
$$

For ${ }^{12} \mathrm{C}$ the coefficient $\rho$ is written as a function of temperature (Sestak, et al. $\left.{ }^{50}\right)$ :

$$
\rho=1.977 \times 10^{-3}-6.5 \times 10^{-6} \cdot \mathrm{T},
$$

where $T$ is the average hourly temperature. For ${ }^{14} \mathrm{C}, \rho$ is calculated as the $\rho$ for ${ }^{12} \mathrm{C}$ times the isotopic ratio of $1.045 \mathrm{~g}^{14} \mathrm{CO}_{2} / \mathrm{g}^{12} \mathrm{CO}_{2}$. 
The total growth rate of the crop species in $\mathrm{gC} \mathrm{m}^{-2} \mathrm{~h}^{-1}$ is calculated by multiplying the net mass flux of carbon by the leaf area index of the crop:

$$
n_{G_{T}}=n_{F_{m}} \cdot L A I \cdot c \cdot 10^{4},
$$

where

$$
\begin{aligned}
& { }_{F_{m}}=\text { net mass flux of carbon exchange }\left(\mathrm{g} \cdot \mathrm{cm}^{-2} \cdot \mathrm{h}^{-1}\right), \\
& \text { LAI }=\text { leaf area index }\left(\mathrm{m}^{2} / \mathrm{m}^{2}\right), \\
& c \quad=\text { stoichiometric coefficient to convert } \mathrm{CO}_{2} \text { to } \mathrm{C}(\mathrm{g} / \mathrm{g}) .
\end{aligned}
$$

The coefficient $c$ is derived from the summary equation for photosynthes is (Sestak, et al. ${ }^{50}$ ):

$$
6 \mathrm{CO}_{2}+{ }^{12} \mathrm{H}_{2} \mathrm{O} \longrightarrow \mathrm{C}_{6} \mathrm{H}_{12} \mathrm{O}_{6}+6 \mathrm{H}_{2} \mathrm{O}+6 \mathrm{O}_{2}
$$

Since six molecules of $\mathrm{CO}_{2}$ are required to make a single molecule of glucose, the constant.c is calculated by using the fractional molecular weights of carbon to $\mathrm{CO}_{2}$ and sugar $\left(\mathrm{C}_{6} \mathrm{H}_{10} \mathrm{O}_{5}\right)$ :

$\frac{6 \text { - molecular weight of carbon/molecular weight of sugar }}{6 \cdot \text { molecular weight of carbon/molecular weight of } \mathrm{CO}_{2}}$

For ${ }^{12} \mathrm{C}$, the value of $c$ is 0.2716 and for ${ }^{14} \mathrm{C}$ it is 0.2644 . The growth rate of leaves $\left({ }^{n} G_{L}\right)$ is assumed to be a specified fraction of ${ }^{n} G_{T}$.

\subsubsection{Leaf mortality rate}

The total leaf mortality rate $\left(M_{T L}\right)$ is written as a function of total leaf carbon. For each carbon isotope, the rate of leaf mortality is expressed as the isotope fraction of total leaf carbon times the totai mortality rate. The total mortality rate $\left(D i x o n^{51}\right)$ is 


$$
M_{T L}=C_{T L} \cdot \gamma_{1} /\left[1+e^{\left(2.2 / \gamma_{3}\right)\left(\gamma_{2}-t\right)}\right]
$$

where

$$
\begin{aligned}
& \gamma_{1}=\text { maximum leaf fall rate constant }\left(\mathrm{hr}^{-1}\right) \\
& \gamma_{2}=\text { time of maximum leaf fall (hr) } \\
& \gamma_{3}=\text { time between } 0.1 \text { and } 0.5 \text { total leaf fall (hr) }
\end{aligned}
$$

The individual isotope leaf mortality rates are

$$
{ }^{1 H_{M}}=\left({ }^{14} C_{L} / C_{I L}\right) M_{T L}
$$

for ${ }^{14} \mathrm{C}$ and

$$
{ }^{12} M_{L}=\left({ }^{14} C_{L} / C_{T L}\right) M_{T L}
$$

for ${ }^{12} \mathrm{C}$.

\subsubsection{Leaf Respiration Rates}

Leaf respiration rate, as with leaf mortality, is a function or total leaf carbon. Since photorespiration is considered implicitly in the calculation of photosynthesis, only dark respiration is calculated. The dark respiration rate for total leaf carbon is:

$$
R_{T L}=L A I \cdot 10^{4} \cdot R_{\text {std }} \cdot 2^{(T-22) / 10} \text {, }
$$

where

$$
\begin{aligned}
\mathrm{R}_{\text {std }} & =\text { standard dark respiration rate }\left(\mathrm{gC} \mathrm{cm}^{-2} \mathrm{hr}^{-1}\right) \text {, and } \\
\mathrm{T} & =\text { average hourly temperature }\left({ }^{\circ} \mathrm{C}\right) .
\end{aligned}
$$

The respiration rates for each carbon isotope are expressed by 


$$
{ }^{14} R_{L}=\left({ }^{14} C_{L} / C_{T L}\right) R_{T L}
$$

for ${ }^{14} \mathrm{C}$ and

$$
{ }^{12} \mathrm{R}_{\mathrm{L}}=\left({ }^{12} \mathrm{C}_{\mathrm{L}} / \mathrm{C}_{\mathrm{TL}}\right) \dot{\mathrm{R}}_{\mathrm{TL}}
$$

for ${ }^{12} \mathrm{C}$.

\subsubsection{Incorporation of ${ }^{14} \mathrm{C}$ Concentration in the Carbon Assimilation Model (CAM)}

A first step in the incorporation of ${ }^{14} \mathrm{C}$ concentration into the CAM is to calculate the natural ambient ${ }^{14} \mathrm{C}$ concentration in the year 1985 the assumed on-line date for the HTGR reprocessing facility. The estimated ${ }^{14} \mathrm{C}$ to total carbon ratio in 1985 is $1.83 \times 10^{-12}$ (Fairhall and Young ${ }^{5}$ ). Multiplying this value by the projected ${ }^{46} \mathrm{CO}_{2}$ concentration in 1985 of $3.4 \times 10^{-4} \mathrm{~cm}^{3} / \mathrm{cm}^{3}$ yields an estimated 1985 natural ambient ${ }^{14} \mathrm{CO}_{2}$. concentration of $6.2 \times 10^{-16} \mathrm{~cm}^{3} / \mathrm{cm}^{3}$.

The above ambient calculations of ${ }^{14} \mathrm{CO}_{2}$ as $\mathrm{Ci} / \mathrm{m}^{3}$ presented in $\mathrm{Sec}$. 2.2.3.5 provide the basis for calculating hourly above-background ${ }^{14} \mathrm{CO}_{2}$ concentrations as fractional volume. The maximum plume event concentrations are added to the natural ambient concentration for each daytime stability class-wind speed class combination for. two stack heights (Table 8) to provide estimates of tota $1{ }^{14} \mathrm{CO}_{2}$ atmospheric concentrations. It is convenient to express these concentrations as a vector $c=\left\langle c_{1}, c_{2}, \ldots\right.$, $\mathrm{c}_{6}$ ) in which the first five components are the concentrations in a column of Table 8 and the sixth component is the natural ambient concentrations. Also needed for calculation of hourly ${ }^{14} \mathrm{CO}_{2}$ concentrations are the daytime fractional occurrences of each stability class and wind speed combination (Table 9). These tabled values also can be expressed as a matrix. We can write: 
Table 8. Maximum ground level concentrations of ${ }^{14} \mathrm{CO}_{2}$ for two stack heigh $\doteqdot$ expressed as fraction by volume $\left(\mathrm{cm}^{3} / \mathrm{cm}^{3}\right)$.

\begin{tabular}{|c|c|c|c|c|c|c|}
\hline \multirow{3}{*}{$\begin{array}{l}\text { Stability } \\
\text { Class }\end{array}$} & \multirow{3}{*}{$\begin{array}{c}\text { Wind Speed } \\
\text { Class }\end{array}$} & \multicolumn{5}{|c|}{ Distance from Stack } \\
\hline & & $509 \mathrm{~m}^{\mathrm{a}}$ & \multicolumn{2}{|c|}{$1 \mathrm{~km}$} & \multicolumn{2}{|c|}{$10 \mathrm{~km}$} \\
\hline & & $300 \mathrm{ft} \mathrm{S}=\mathrm{ack}$ & $300 \mathrm{ft}$ Stack & $1000 \mathrm{ft}$ Stack & $300 \mathrm{ft}$ Stack & $1000 \mathrm{ft}$ Stack \\
\hline 1 & 1 & $1.3 \times 10^{-12}$ & $5 . ? \times 10^{-33}$ & $6.2 \times 10^{-26}$ & $1.5 \times 10^{-14}$ & $1.0 \times 10^{-14}$ \\
\hline 1 & 2 & $5.1 \times 10^{-13}$ & $2.1 \times 10^{-13}$ & $3.3 \times 10^{-15}$ & $5.8 \times 10^{-15}$ & $4.8 \times 10^{-15}$ \\
\hline 1 & 3 & $3.0 \times 10^{-13}$ & $1.2 \times 10^{-13}$ & $1.0 \times 10^{-14}$ & $3.5 \times 10^{-15}$ & $2.9 \times 10^{-15}$ \\
\hline 4 & 3 & $4.4 \times 10^{-15}$ & $1.7 \times 10^{-13}$ & $6.6 \times 10^{-16}$ & $3.6 \times 10^{-14}$ & $9.2 \times 10^{-15}$ \\
\hline 4 & 4 & $3.7 \times 10^{-15}$ & $9.5 \times 10^{-14}$ & $6.2 \times 10^{-16}$ & $2.3 \times 10^{-14}$ & $7.8 \times 10^{-15}$ \\
\hline
\end{tabular}

${ }^{a}$ Ground level conceritrations at $500 \mathrm{~m}$ from a $1000 \mathrm{ft}$ stack are not significantly higher than background concentrations. 
Table 9. Fractional daytime occurrence of important stability classes and wind speed conditions.

\begin{tabular}{ccccccccc}
\hline $\begin{array}{c}\text { Stability } \\
\text { Class }\end{array}$ & $\begin{array}{c}\text { Wind Speed } \\
\text { Class }\end{array}$ & April & May & June & July & August & September & October \\
\hline 1 & 1 & 0.0 & 0.0136 & 0.0479 & 0.0821 & 0.0080 & 0.0084 & 0.0056 \\
1 & 2 & 0.0286 & 0.0272 & 0.0592 & 0.0238 & 0.0486 & 0.0641 & 0.0084 \\
1 & 3 & 0.0344 & 0.0218 & 0.0310 & 0.0207 & 0.0703 & 0.0615 & 0.0224 \\
4 & 3 & 0.0072 & 0.0095 & 0.0198 & 0.0223 & 0.0027 & 0.0097 & 0.0070 \\
4 & 4 & 0.0230 & 0.0149 & 0.0 & 0.0103 & 0.0094 & 0.0209 & 0.0112 \\
& & & & & & & & \\
$\begin{array}{c}\text { Conditions other } \\
\text { than above }\end{array}$ & & 0.9068 & 0.9130 & 0.8421 & 0.8408 & 0.8610 & 0.8354 & 0.9454 \\
\hline
\end{tabular}




$$
P=\left\|P_{i j}\right\| i=1,2, \ldots, 6 ; j=1,2, \ldots, 7
$$

where $i$ is the stability class - wind speed class and $j$ is the month (April through October).

A cumulative probability distribution is calculated for each month and written in matrix notation as $A=\left\|a_{i j}\right\|$ where:

$$
a_{i j}= \begin{cases}P_{1 j} & i=1 \\ a_{i-1, j}+P_{i j} & i>1\end{cases}
$$

and $i$ and $j$ are defined as before.

Since the stability class and wind speed class combinations are defined by month (Table 9) and the carbon assimilation model uses a timestep of an hour, it is necessary to define $j$ according to sequential hours per month:

$$
j- \begin{cases}1 & 2160 \leq \mathrm{t}<2940 \\ 2 & 2904 \leq \mathrm{t}<3648 \\ 3 & 3648 \leq \mathrm{t}<4368 \\ 1 & 1368 \leq \mathrm{t}<5112 \\ 5 & 5112 \leq \mathrm{t}<5856 \\ 6 & 5856 \leq \mathrm{t}<6576 \\ 7 & 6576 \leq \mathrm{t}<8760\end{cases}
$$

Finally a value of ground-level ${ }^{14} \mathrm{CO}_{2}$ (from the vector $c$ ) is obtained each hour by sampling the cumulative probability distribution of the month in which the current hour falls. A uniform distribtuion random number generator with random variable $x$ is used such that for each month $j$ : 


$$
{ }^{14} \mathrm{CO}_{2 a}=\left\{\begin{array}{ll}
c_{1} & 0 \leq x \leq a_{1, j} \\
c_{2} & a_{1, j}<x \leq a_{2, j} \\
c_{3} & a_{2, j}<x \leq a_{3, j} \\
c_{4} & a_{3, j}<x \leq a_{4, j} \\
c_{5} & a_{4, j}<x \leq a_{5, j} \\
c_{6} & a_{5, j}<x \leq 1
\end{array},\right.
$$

If $x$ corresponds to a nighttime hour, however, the uptake rates for ${ }^{12} \mathrm{C}$ and ${ }^{14} \mathrm{C}$ are set to zero.

\subsubsection{Estimates of ${ }^{14} \mathrm{C}$ Assimilation}

Rates of carbon assimilation increase whenever the ambient $\mathrm{CO}_{2}$ con-. centrations are increased. Because the net assimilation rates are much higher than respiration or mortality rates at the beginning of the growing season, the assimilated ${ }^{14} \mathrm{C}$ is retained in the plant; near the end of the growing season, this trend is reversed. In order to show the response of plants to the plume events, the results of a simulation during five days in July are shown in Fig. 5. Included in this figure are the hours of day and night, the plume events, and the carbon-14 in plant leaves. Note that whenever a plume event occurs in daylight the carbon-14 in leaves increases. No accumulation occurs at night since the photosynthetic process requires light to function. Plume events do occur at night but with different probabilities than in the daytime.

For the speciftc case using Oak Ridge area meteorological conditions, CAM predicted a maximum specific activity in plant leaves $\left(S_{p}\right)$ of $1.84 \times$ $10^{-9} \mathrm{Ct} / \mathrm{gC}$ at a point $500 \mathrm{~m}$ from the $300-\mathrm{ft}$ stack. Figure 6 shows a plot of $S_{p}$ superimposed on a bar graph of the monthly averages of the ambient 


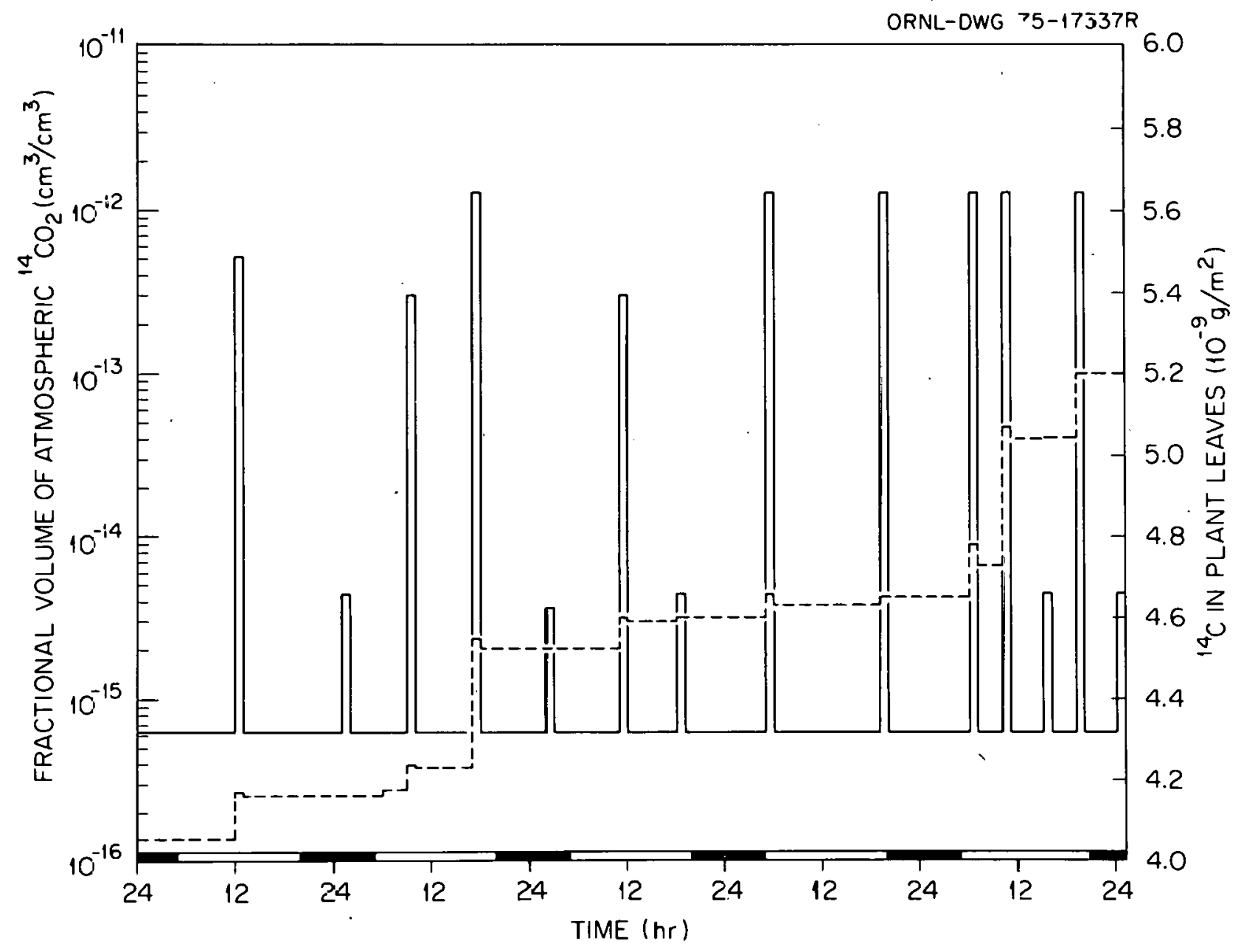

Fig. 5. Grounc level atmospheric concentrations of ${ }^{14} \mathrm{CO}_{2}$ (solid line) and $14 \mathrm{C}$ content in leaves (cashed line) simulated for five days during the growing season at $500 \mathrm{~m}$ from the $300-\mathrm{ft}$ stack. The hours of dark and daylight are represented by solid and clear bars, respectively. 


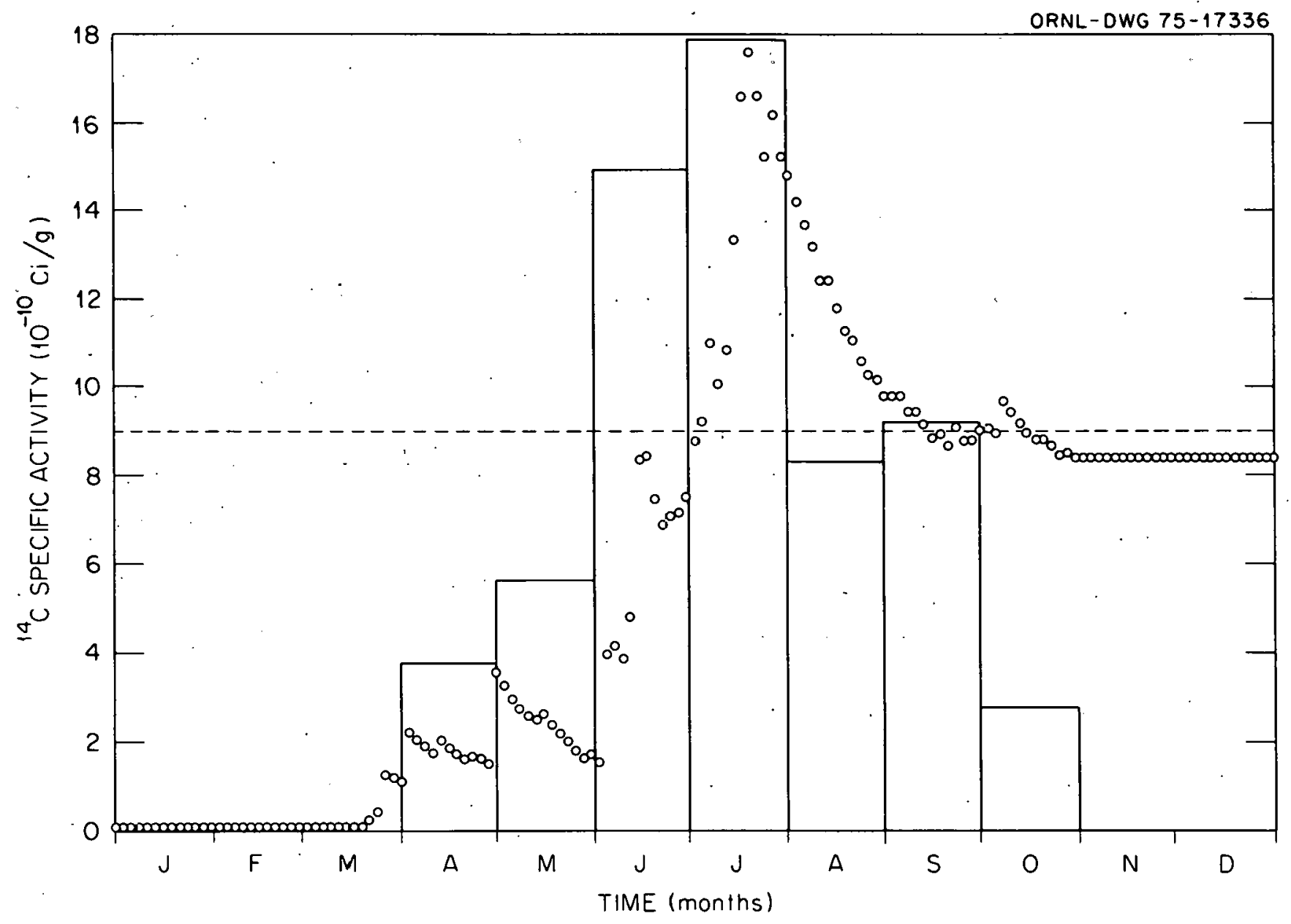

Fig. 6. Simulated history of specific activity of ${ }^{14} \mathrm{C}$ in plant leaves (plotted points). The solid bars show the monthly averaged specific activity in the ambient air during daylight hours, and the dashed line represents the corresponding average for the growing season. 
specific activity during daylight hours. The dashed line represents the ambient seasonal daylight average, $\bar{S}_{a}$. The increased frequency of plume events during June and July accounts for the steep rise in leaf specific activity, shown in Fig. 6, to its maximum, which occurs in the latter half of July. Afterward, this quantity recedes toward the seasonal average in response to the decreasing frequency of plume events, and accordingly, the ratio $S_{p} / \bar{S}_{a}$ decreases from its maximum $(\simeq 2)$ and returns to values near unity during September.

For the simulation plotted in Fig. 6 , the calculated seasonal ${ }^{14} \mathrm{CO}_{2}$ concentration is $6.22 \times 10^{-14} \mathrm{~cm}^{3} / \mathrm{cm}^{3}$. This value is divided by $3.4 \mathrm{x}$ $10^{-4} \mathrm{~cm}^{3} / \mathrm{cm}^{3}$, the estimated 1985 atmospheric $\mathrm{CO}_{2}$ concentration, to obtain the ${ }^{14} \mathrm{CO}_{2} /{ }^{12} \mathrm{CO}_{2}$ ratio of $1.83 \times 10^{-10}$. Multiplying this value by the isotopic density ratio 1.116 yields a ratio of $2.04 \times 10^{-10} \mathrm{~g}^{14} \mathrm{C} / \mathrm{gC}$ in the atmosphere. This value times $4.46 \mathrm{Ci} / \mathrm{g}^{14} \mathrm{C}$ gives an average specific activity of $9.10 \times 10^{-10} \mathrm{Ci} / \mathrm{gC}$. If we assume that vegetaliun is in equilibrium with the average atmospheric specific activity, the spectflc activity in plant tissue would also equal $9.10 \times 10^{-10} \mathrm{Ci} / \mathrm{gC}$. The maximum ${ }^{14} \mathrm{C}$ specific activity in plant leaves $\left(S_{p}\right)$ based on the CAM simulation is $1.84 \times 10^{-9} \mathrm{Ci} / \mathrm{gC}$, from which we calculate $\max \left(\mathrm{S}_{\mathrm{p}} / \overline{\mathrm{S}}_{\mathrm{a}}\right)=2.02$.

We emphasize that information obtained from the model in this simulation is highly tentative, and such numeric transfer factors as might be inferred from it must be considered preliminary until validation experiments can be performed. If the validity of the model were stipulated, the appropriate transfer factor for vegetation raised under these exposure conditions would depend upon the distribution of harvest times in the growing season, and this would be specific to the particular kind of plant. 
Moreover, a composite transfer factor for the carbon that man ingests would have to take into account specific factors for all vegetation links in his food chain, including forage and silage crops consumed by beef and poultry.

Because of the lack of direct experimental corroboration of the model's predictions, the evidence is judged insufficient at this time to support the recommendation of any transfer factor greater than unity for use in dose estimates to man from the ingestion of ${ }^{14} \mathrm{C}$.

\section{RADIOLOGICAL IMPACTS TO INDIVIDUALS AND POPULATIONS IN THE VICINITY OF A HTGR REPROCESSING FACILITY}

\subsection{Exposure Scenarios}

Dose estimates were computed (1) for a hypothetical maximally exposed individual (fence-post man), (2) an average individual within approximately 50 miles of the facility site, and (3) for a population of $10^{6}$ individuals uniformly distributed over the same area.

The two modes of release discussed in Sec. 2.2.3.1 involved a 300-ft stack with no thermal discharge and a 1000-ft stack with a specified thermal discharge accompanying the ${ }^{14} \mathrm{C}$ release. For the sake of brevity, we shall refer to these cases simply as the "300-ft stack" and "1000-ft stack". cases, respectively.

In each of these cases, two grids have been superimposed upon the region around the facility. The first, or "large grid," fits into an approximately square area 100 miles $\times 100$ miles, with the facility $10-$ cated at the center, and with sides oriented north-south and east-west. The grid is a network of $11 \times 11=121$ points spaced at north-south or 
east-west increments of $10 \mathrm{mi}$. The second, or "small grid," is similarly oriented with respect to a square $10 \mathrm{mi} \times 10 \mathrm{mi}$ and consists of $21 \times 21=$ 441 points spaced at intervals of $0.5 \mathrm{mi}$. The facility was assumed to occupy the central square mile of each grid, with the stack in the exact center.

The atmospheric transport methodology of Sec. 2.2 was used to predict, for the hypothesized release from each stack, the resulting time-averaged ground-level air concentrations of ${ }^{14} \mathrm{C}$ at each point of both grids. Because of the organization of the computer data file containing the meteorological information, these concentrations were averaged with respect to the 24-hour day; both annual and growing-season (April through October) averages were calculated. A special computation was undertaken to furnish, for selected points, concentrations which represent growing-season averages for daylight hours only (with daylight defined as geometric sunrise to sunset). These special values were used to derive conversion factors for extrapolating the daylight-averaged concentrations to averages over the regions covered by the small and large grids; in addition, the special points were chosen to include the location of the maximally exposed individual ("fence-post" man). Inhalation dose components were estimated from the annual average concentrations; uptake by ingestion, however, is dependent upon photosynthesis, and the seasonal daylight average concentrations are therefore appropriate for estimating the ingestion component, which ordinarily accounts for more than 99 percent of the dose.

It is appropriate to point out that significant differences between these two seasonal averages (daylight vs 24-hour) exist in the 0ak Ridge meteorology and should be examined in any meteorology which is used for 
this type of assessment. The difference between annual and seasonal concentrations, when averaged over the large grid, was not significant for either stack, but was pronounced at points close to the stack.

The dose-rate factors of Table 6 are based on the assumption that a steady-state ambient specific activity of ${ }^{14} \mathrm{C}$ produces the same specific activity in man's tissues, provided all dietary intakes are exposed to the same ambient levels that he breathes. Extrapolation from this model permits a mixture of intakes at different specific activities.

The maximally exposed individual was assumed to live at the grid point where the highest concentrations occurred and to raise all food on site. In the Oak Ridge area meteorology, a radial drawn from the stack in the northeast direction defines a corridor of high concentration, which contains the maximum grid point for each stack height. For the $300-\mathrm{ft}$ stack, the concentrations are highest at the grid point closest to the stack ( 0.707 miles), and in the case of the 1000-ft stack, the maximum point is the next point to the northeast $(1.41$ miles). The concentrations at these points were used to calculate dose estimates for the maximally expused indtvidual. These estimates are presented in Sec. 3.2.

The basic assumptions taken in calculating averaged dose estimates for the area covered by either grid were the following:

(1) Population is geographically uniformly distributed.

(2) Each individual receives a dietary intake of 300 grams of carbon per day, the sources of which are uniformly distributed over the large grid area.

Area-averaged concentrations were therefore computed as arithmetic means of time-averaged concentrations at the grid points of the area in question, 
and the results were applied to calculating the corresponding areaaveraged dose estimates. Components due to inhalation and ingestion were analyzed, but only the latter are significant for the exposure situations of interest. We note, however, that an average resident of the small grid has an inhalation component that accounts for 30 percent of the total dose, if we assume the conservative ratio of uptake fractions $f_{a} / f_{w}=0.75$; this effect derives from the locally elevated concentration of ${ }^{14} \mathrm{C}$ in the air he breathes, whereas his dietary uptake is the same as that of the average large-grid resident. But the differential effect diminishes rapidly as distance from the stack increases. Average doses to area inhabitants are given in Sec. 3.3 .

For each stack, the dose (man-rem) to population in the large-grid area was estimated for one year of operation of the reprocessing facility; a population of $10^{6}$ persons was assumed for this calculation. These doses represent integrations of the respective dose rates over the one year of operation; they do not contain the component that would be delivered over the long term by the residual increment in world-wide atmospheric specific activity contributed by the ${ }^{14} \mathrm{C}$ release during the single year of operation.

A11 dose estimates given in Secs. 3.2, 3.3, and 3.4 apply to total body. Dose rates or doses to other organs may be calculated by the appropriate ratio of dose rate factors from Table 2.

The population doses are presented in Sec. 3.4.

\subsection{Dose to the Maximally Exposed Individual}

With the models under discussion, the maximum inhalation dose would result from continuous habitation where the annual 24-hour average aị 
concentration of ${ }^{14} \mathrm{C}$ is maximum, and the largest ingestion dose would come from the direct consumption of vegetation produced at the point where the daylight seasonal average concentration' is greatest, and from eating the meat and drinking the milk of cattle fed on vegetation produced at the same location. For the 300-ft stack, both concentrations are maximum at the nearest point of the small grid northeast of the stack $\left(0.707\right.$ miles, $35^{\circ} 55^{\prime} 26^{\prime \prime} \mathrm{N}$ by $\left.84^{\circ} 19^{\prime} 28^{\prime \prime} \mathrm{W}\right)$; in the case of the $1000-$ ft stack, both are maximum at the second small-grid point northeast of the stack ( 1.41 miles, $35^{\circ} 55^{\prime} 52^{\prime \prime} \mathrm{N}$ by $\left.84^{\circ} 18^{\prime} 56^{\prime \prime} \mathrm{W}\right)$. Each of these points will be referred to as the "maximum point" for its respective stack. The coordinates of the stack, in each case, are $35^{\circ} 55^{\prime} 0^{\prime \prime} \mathrm{N}$ by $84^{\circ} 20^{\prime} 0^{\prime \prime} \mathrm{W}$.

The following table displays the two concentrations and the resulting dose rates to the fence-post man for each stack height. Natural background concentration and dose rate are shown for comparison. Parenthesized dose rates are for $1 \mathrm{Ci} / \mathrm{yr}(=1 / 5000$ of the assumed release rate).

\begin{tabular}{|c|c|c|c|}
\hline & $\begin{array}{c}\text { 24-Hour Annual } \\
\text { Concentration } \\
\left(\mathrm{Ci} / \mathrm{m}^{3}\right)\end{array}$ & $\begin{array}{c}\text { Daylight Seasonal } \\
\text { Concentration } \\
\left(\mathrm{Ci} / \mathrm{m}^{3}\right)\end{array}$ & $\begin{array}{l}\text { Total Body } \\
\text { Dose Rate } \\
\text { (mrem/yr) }\end{array}$ \\
\hline $300-f t$ stack & $3.19 \times 10^{-11}$ & $6.66 \times 10^{-11}$ & $\left(1.7 \times 10^{-2}\right)$ \\
\hline 1000-ft stack & $1.79 \times 10^{-12}$ & $4.17 \times 10^{-12}$ & $\left(1.1^{5.5} \times 10^{-3}\right)$ \\
\hline Natura $1{ }^{14} \mathrm{C}$ & $9.76 \times 10^{-13}$ & $9.76 \times 10^{-13}$ & 1.3 \\
\hline
\end{tabular}

The 21-hr annual concentrations are presented for comparison purposes, but more than 99 percent of each dose rate is attributable to the 
ingestion mode, which depends on the daylight seasonal concentration.

Thus to the precision shown, each dose rate may be calculated as the product of the daylight seasonal concentration and the dose rate factor 1.31 x $10^{12} \mathrm{mrem} / \mathrm{yr}$ per $\mathrm{Ci} / \mathrm{m}^{3}$ from Table 6 .

3.3 Average Individual Within the 10- and 100-mile Squares

Doses to the average adult individual in each grid system have been estimated. The average small-grid resident is of some interest because a conservative assumption regarding the inhalation uptake fraction $\left(f_{a} / f_{w}\right.$ $=0.75$ ) results in an inhalation component that is approximately 30 percent of the total dose.

The following table shows, for each stack, the inhalation, ingestion, and total dose rates to total body for the average resident of the small grid versus two assumed uptake ratios $f_{a} / f_{w}$. The first ratio (ICRP Publication $2^{29}$ ) is conservative and probably inappropriate; the second was derived from Bernard ${ }^{32}$ and is believed to be a more realistic representation. This point was discussed in Sec. 1.3.5.

\begin{tabular}{llccc} 
& \multicolumn{4}{c}{ Total-Body Dose Rate (mrem/yr) } \\
\cline { 2 - 5 } $\mathrm{f}_{\mathrm{a}} / \mathrm{f}_{\mathrm{w}}$ & Inhalation & Ingestion & Total & Tota1/5000 Ci \\
\hline & & $300-\mathrm{ft}$ Stack \\
0.75 & $4.79 \times 10^{-2}$ & 0.106 & 0.154 & $3.08 \times 10^{-5}$ \\
0.01 & $6.42 \times 10^{-4}$ & 0.107 & 0.108 & $2.16 \times 10^{-5}$
\end{tabular}

1000-ft Stack
0.75
$3.84 \times 10^{-3}$
$6.24 \times 10^{-2}$
$6.62 \times 10^{-2}$
$1.32 \times 10^{-5}$
0.01
$5.14 \times 10^{-5}$
$6.30 \times 10^{-2}$
$6.32 \times 10^{-2}$
$1.26 \times 10^{-5}$ 
It is clear from the table that if the latter assumption is taken, the component of dose due to inhalation remains minor for the average resident of the small grid.

The total-body dose rates (mrem/yr) for the average resident of the large-grid area are as follows (parenthesized values are mrem/yr per $\mathrm{Ci}$ / yr of release):

$\begin{array}{ccc}300-\mathrm{ft} \text { stack } & 0.11 & \left(2.2 \times 10^{-5}\right) \\ 1000-\mathrm{ft} \text { stack } & 6.3 \times 10^{-2} & \left(1.3 \times 10^{-5}\right) \\ \text { Natura }{ }^{14} \mathrm{C} & 1.3 & \end{array}$

For the average resident of the large-grid area, the inhalation component of the dose is negligible.

\subsection{Local Population Dose}

Estimates of dose to the local (1arge-grid) population (man-rem) were computed from the average dose rates of Sec. 3.3. These population dose estimates reflect one year of operation of the reprocessing facility. A population of $10^{6}$ individuals has been assumed, which is uniformly distributed over the large grid area and which receives dietary carbon intakes in equal proportions from uniformly distributed sources (assumptions (1) and (2) from Sec. 3.1).

The population dose estimates are as follows:

\begin{tabular}{lrc}
\cline { 2 - 3 } & man-rem & man-rem/Ci \\
\cline { 2 - 3 } 300 -ft stack & 110 & $2.2 \times 10^{-2}$ \\
1000 -ft stack & 63 & $1.3 \times 10^{-2}$ \\
Natural ${ }^{14} \mathrm{C}$ & 1300 &
\end{tabular}


These population doses should not be interpreted as total dose commitments to the local population from one year of operation of the facility; such a commitment would contain the component that would be delivered over the longer term by the residual increment in the world-wide atmospheric ${ }^{14} \mathrm{C}$ specific activity that is contributed by the release during the year of operation. A large fraction of the release eventually goes into the deep ocean and is retained there with a mean residence time of centuries, but a portion remains airborne, subject only to radioactive decay and dilution by the increasing inventory of ${ }^{12} \mathrm{C}$. This airborne fraction of ${ }^{14} \mathrm{C}$, distributed world wide, delivers its dose to populations over a period of thousands of years.

\subsection{CONCLUSIONS AND RECOMMENDATIONS}

The information presented in this report leads to a number of conclusions and recommendations. Some recommendations suggest further research; others are applicable to site-specific assessments that might be performed for HTGR and other facilities which release ${ }^{14} \mathrm{C}$ into the atmosphere.

In Sec. 1.2.2, calculations of amounts of natural and excess ${ }^{14} \mathrm{C}$ present in terrestrial biota were described, and it was pointed out that the resulting estimates were somewhat higher than corresponding values reported in the literature. Taken together, estimates of terrestrial distribution in the present analysis and the more precisely measured oceanic distribution are in acceptable agreement with theoretically calculated yields from weapons testing. The question which remains to be investigated is whether this biospheric partitioning significantly alters previous 
estimates of dose commitment to the world's population. We recommend that existing dose estimates be reviewed in the light of this question.

Internal dose-rate factors for several reference organs of man were computed from recently published information and presented in Sec. 1.3.6. These factors are based on the ${ }^{14} \mathrm{C}$ specific activity in man's tissues. Their use for steady-state dose rate calculations is believed to be preferable to the adoption of corresponding estimates based on existing metabolic models, specifically those of ICRP Publications $2^{29}$ and $10 .^{30}$

Atmospheric transport calculations have been carried out to predict concentrations of releases ${ }^{14} \mathrm{C}$ over the local area surrounding the model facility. The resulting concentrations depend on the particular meteorology (which, for this study, was that of the Oak Ridge area), and they are also functions of several stack and release parameters (release rate, stack height and diameter, and exhaust gas temperature and velocity) for which specific values were chosen. In particular, calculations were done with two stack heights and exit-gas temperatures, and the results indicated a significant reduction in the fence post dose when a 1000-ft stack with $80^{\circ} \mathrm{C}$ gas temperature replaces a $300-\mathrm{ft}$ stack releasing gas at ambient temperature. The dependence of the maximum dose on these parameters needs to be explored further in order to provide information for stack design and release control engineering.

The dependence of the dose on the specific meteorology also needs to be examined. There is reason to believe that the Oak Ridge meteorology tends to lead to a larger fence post dose because of its higher frequency of daytime Class $\mathrm{A}$ (unstable) conditions. To the extent practicable, a range of fence post concentrations should be estimated for near-extreme meteorólogies. 
For the Oak Ridge meteorology, calculations revelaed that replacing the 24 -hour annual average ${ }^{14} \mathrm{C}$ concentration in the air by an average taken with respect to daylight hours during the growing season increases the fence post ingestion dose component by a factor of about two. It is suggested that the latter average is the more appropriate basis for the estimation of the ingestion dose, whereas the former should be used for the inhalation exposure mode.

The possibility of restricting some fraction of the ${ }^{14} \mathrm{C}$ release to nighttime hours might be considered. Calculations for this report assumed a uniform release rate throughout each day and night of the year. Thus some reduction in local dose rates is possible by an increase in the nocturnal fraction of the release. But such a procedure would in no way reduce the global impact of the release.

Finally, calculations done with a plant growth carbon assimilation model (CAM) have suggested the possibility that in the presence of frequent meteorological events that produce sporadic high ${ }^{14} \mathrm{C}$ concentrations, the time-averaged ambient specific activity may underestimate the maximum specific activity likely to occur in the tissue of a plant growing in such an exposure environment. Published information is inadequate to corroborate or reject this result, and the relevance of the the question to the estimation of the transfer of ${ }^{14} \mathrm{C}$ to man through his food chatn indicates a need for continuing efforts to validate the model. 


\section{REFERENCES}

1. H. Schroeder, Die jährliche Gesamtproduktion dér grünen Pflanzendecke der Erde, Naturwiss. 7, 8-12 (1919).

2. J. von Liebig, Die Chemie in ihrer Anwendung usw, VII. Auflage, Band I, 263 (1862).

3. E. W. F. Ebermayer, Die gesammte Lehre der Waldstreu mit Rücksicht auf die chemische Statik des Waldbaues. Berlin, J. Springer (1876).

4. L. H. Brooks, C. A. Heath, B. Kirstein, and D. G. Roberts, Carbon-14 in the HTGR Fuel Cycle, General Atomic Company, GA-A13174 UC-77 (1974).

5. A. W. Fairhall and J. A. Young, Radiocarbon in the Environment:

Radionuclides in the Environment, Advances in Chemistry Series No. 95, Amer. Chem. Soc., 401-418 (1970).

6. V. M. Goldschmidt, Carbon, in Geochemistry, A. Muir (ed.), Oxford, Clarendon Press (1954).

7. J. S. 01son, Carbon cycle and temperate woodlands, in Analysis of Temperate Forest Ecosystems, D. E. Reichle (ed.), New York-HeidelbergBerlin, Springer-Verlag (1970).

8. H. Lieth, Predicted annual fixation of carbon for the landmasses and oceans of the world (after H. Lieth 1964/65: Geographisches Taschenbuch, Steiner Verlag GmbH, Wiesbaden), in Analysis of Temperate Forest Ecosystems, D. E. Reichle (ed.), New York-Heidelbert-Berlin, SpringerVerlag (1970).

9. H. Craig; The national distribution of radiocarbon and the exchange time of carbon dioxide between atmosphere and sea, Telius $\underline{9}$ (1), 1-17, (1957). 


\section{REFERENCES, continued}

10. L. Machta, Mauna Loa and global trends in air quality, Bull. Am. Met. Soc. $\underline{53}, 402-420$ (1972).

11. B. Bolin, The carbon cycle, Sci. Amer. 223, 124-132 (1970).

12. J. Cramer and A. L. Myers, Rate of increase of atmospheric carbon dioxide, Atmospheric Environment, Pergamon Press ㅁ, 563-573 (1972).

13. V. Smil and D. M11ton, Carbur diuxide - alternative futures, Atm. Env. 8, 1213-1223 (1974).

14. R. Nydal, Further investigation on the transfer of radiocarbon in nature, J. of Geophys. Res. 73 (12), 3617-3635, (1968).

15. M. Plesset and A. Latter, Transient effects in the distribution of carbon-14 in nature, Nat'7. Acad. Sci. Proc. 46, 232-241 (1960).

16. SCEP, Man's Impact on the Global Environment: Assessment and Recommendations for Action, Cambridge and London, MIT Press (1970).

17. A. Walton, M. S. Baxter, W. J. Callow, and M. J. Baker, Carbon-14 concentrations in environmental materials and their temporal fluctuations, Proc. of Symp., Monaco, Int. Atomic Energy Agency, Vienna (1967).

18. K. Telegadas, The seasonal atmospheric distribution and inventories of excess carbon-14 from March 1955 to July 1969, USAEC HASL-243, $13-15$ (1971).

19. J. C. Vogel and M. Marais, Pretoria radiocarbon dates I, Radiocarbon 13 (2), 378-394 (1971).

20. A. M. Walton, M. Ergin, and D. D. Harkness, Carbon-14 concentrations in the atmosphere and carbon dioxide exchange rates, J. Geophys. Res. $\underline{75}$ (15), 3089-3098 (1970). 
REFERENCES, continued

21. M. S. Baxter and J. G. Farmer, Glasgow University radiocarbon measurements VII, Radiocarbon 15 (3), 488-492 (1973).

22. D. D. Harkness and A. Walton, Glasgow University radiocarbon measurements IV, Radiocarbon 14 (1), 111-113 (1972).

23. H. Tauber, Copenhagen radiocarbon measurements VIII: Geographic variations in atmospheric ${ }^{14} \mathrm{C}$ activity, Radiocarbon 9 , 246-256.

24. H. Godwin and E. H. Willis, Cambridge University natural radiocarbon measurements IV: Nuclear-weapon testing and the atmospheric radiocarbon concentration, Radiocarbon $\underline{3}, 77-80$ (1961).

25. J. S. 01son, Terrestrial ecosystems, Encyclopedia Britannica, 15th Edition, 144-149, Helen Hemingway Benton, Publisher (1974).

26. A. W. Fairha11, Department of Chemistry, University of Washington, Seattle, Washington. Private communication.

27. J. J. Koranda, Preliminary studies of the persistence of tritium and ${ }^{14} \mathrm{C}$ in the pacific proving ground, Health Phys. 11, 1445-1457 (1965).

28. International Commission on Radiological Protection, Report of the Task Group on Reference Man, ICRP Publication 23, Pergamon Press (1974).

29. International Commission on Radiological Protection, Report of Committe II on permissible Dose for Internal Radiation, ICRP Publication 2, Pergamon Press (1959).

30. International Commission on Radiological Protection, Report of ComMittee IV on Evaluation of Radiation Doses to Body Tissues from Internal Contamination due to Occupational Exposure, ICRP Publication 10, Pergamon Press (1968). 
REFERENCES, continued

31. International Commission on Radiological Protection, Report of Committe IV on the Assessment of Internal Contamination Resulting from Recurrent of Prolonged Uptakes, ICRP Publication 10A, Pergamon Press (1969).

32. S. R. Bernard, A Human Metabolic Model for ${ }^{14}$ C-Labelled Metabolites Usetul in Dose Est1mlliun, Proc. of the Third Int. Congress of the Int. Rad. Protection Assn. (September 1973).

33. P. S. Rohwer, C. J. Barton, and R. E. Moore, Large Scale Nuclear Gas Stimulation: Population Doses Estimated in the Environmental Assessment of Carbon-14 Releases, Proc. of the Eighth Midyear Topical Symposium of the Health Physics Society (October 1974).

34. W. S. Snyder, M. R. Ford, G. G. Warner, and S. B. Watson, A Tabulation of Dose Equivalent per Micorcurie-Day for Source and Target Organs of an Adult for Various Radionucl1des, ORNL-5000 (November $1974)$.

35. G. W. Dolphin and I. S. Eve, Dosimetry of the Gastrointestinal Tract, Health phys. 12, 163-172 (1966).

36. D. K. Trubey and S. V. Kaye, The EXREM III Computer Code for Estimating External Radiation Doses to Populations from Environmental Releases, ORNL-TM-4322 (December 1973).

37. International Commission on Radiological Protection, A Review of the Radiosensitivity of the Tissues in the Bone, ICRP Publication 11, Pergamon Press (1968).

38. M. T. Mills and M. Reeves, A Multi-Source Atmospheric Transport Model for Deposition of Trace Contaminants, ORNL-NSF-EATC-2 (October 1973). 
REFERENCES, continued

39. F. A. Gifford, Jr., An Outline of Theories of Diffusion in the Lower Layers of the Atmosphere, in Meteorology and Atomic Energy, D. H. Slade (ed.), USAEC 1968.

40. G. A. Briggs, Plume Rise, TID-25075, USAEC (1969).

41. R. P. Hosker, Jr., Estimates of Dry Deposition and Plume Depletion over Forests and Grassland, in Proc. of the IAEA Symp. on the Physicla Behavior of Radioactive Contaminants in the Atmosphere, Vienna, Austria (1973).

42. D. B. Turner, Workbook of Atmospheric Dispersion Estimates, Environmental Protection Agency, Research Triangle Park, North Carolina (1970).

43. F. T. Binford, T. P. Hamrick, and Beth H. Cope, Some Techniques for Estimating the Results of the Emission of Radioactive Effluent from ORNL Stacks, ORNL-TM-3187 (October 1970).

44. K. R. Dixon, A Model for Predicting the Effects of Sewage Effluent on Wetland Ecosystems, Ph.D. Dissertation, The University of Michigan, Ann Arbor, Michigan (1974).

45. International Business Machines Corp., Continuous System Modeling Program III (5734-XS9), Program Reference Manua1, Form No. SH19$7001-2(1972)$.

46. H. L. Penman and R. K. Schofield, Some Physical Aspects of Assimilation and Transpiration, in Carbon Dioxide Fixation and Phytosynthesis, Symp. Soc. Exp. Biol. No. 5, New York, Academic Press (1951).

47. M. K. Hughes, Tree biocontent, net production and litter fall in a deciduous woodland, 0ikos 22, 62-73 (1971). 
REFERENCES, continued

48. B. Bolin and E. Eriksson, Changes in the Carbon Dioxide Content of the Atmosphere and Sea due to Fossil Fuel Combustion, in The Atmosphere and the Sea in Motion, Rossby Memorial Volume, Rockefeller Institute Press, New York (1959).

49. J. E. Wuenscher and T. T. Kozlowski, Relationship of gas-exchange resistance to tree-seedling eculugy, Ecology [2, 1016-1023 (19/1).

50. Z. Sestak, J. Catsky, and P. G. Jarvis (eds.), Plant Photosynthetic Production Manual of Methods, Dr. W. Junk N. V. Pub1., The Hague (1971).

51. K. R. Dixon, Analysis of seasonal leaf fall in north temperate deciduous forests, 0ikos (1976, in press).

52. UNSCEAR, Ionizing Radiation: Level and Effects, United Nations Scientific Committee on the Effects of Atomic Radiation, United Nations, New York (1972). 


\section{APPENDIX}

LISTING OF CARBON ASSIMILATION MODEL

AND

GLOSSARY OF VARIABLES AND PARAMETERS 


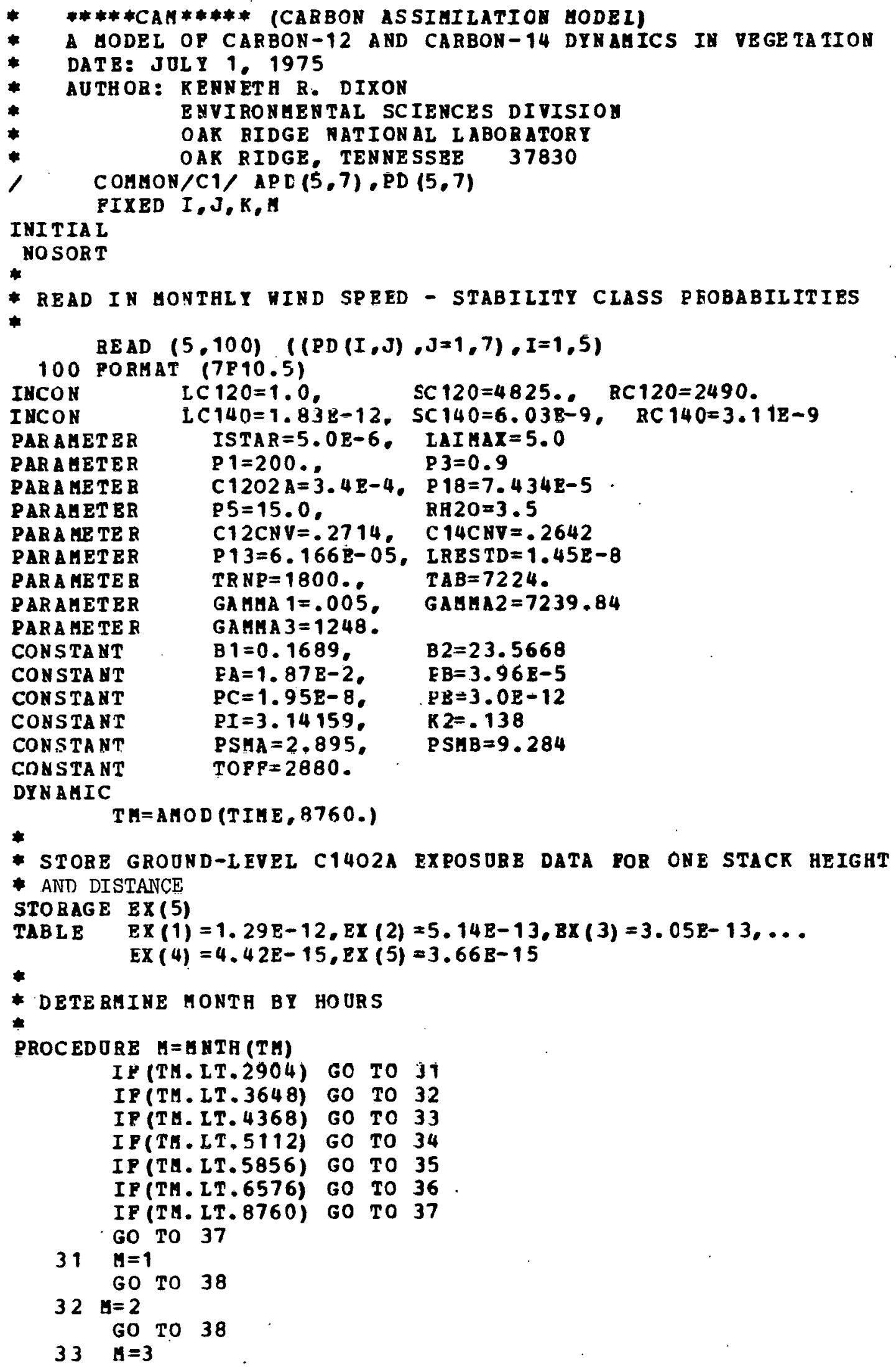




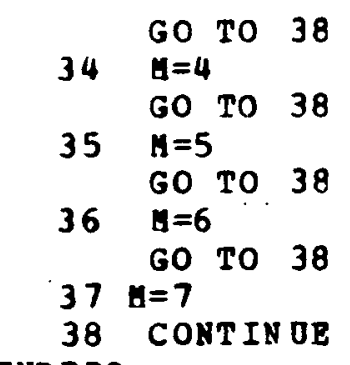

END P BO

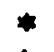

* calculate light and tehpbrature

$*$

TERA5 $=(\operatorname{ISTAR} / 2.0) * \operatorname{SIN}((2 * P I *(18-T H)) / 24)$

$I H=(I S T A R / 6.0)+T E R H 5$

$I T=I N S Y(I H, 0,0, I R)$

TERA $1=15.3 * \operatorname{SIN}((2 * P I *(7320-T B)) / 8760)$

$T$ ERA $2=5.5 * \operatorname{SIN}((2 * P I *(T H-8)) / 24)$

$T H=11.4+T B R H 1+T E R H 2$

$T T=I N S D(T H, 0,0, T$ B)

$B X T=R 2 * L A I$

$I X=I T * B X P(-K 2 * I A I)$

$+$

* calculate co2 concentration at the chloboplast

$*$

PROCEDDRE C $1202 \mathrm{C}=\mathrm{SLO}(\mathrm{T} \mathrm{A})$

IP (TH . IT. 20.) GO TO 7

$C 1202 C=.000250-8.33 E-6 *(T H-20$.

GO TO 8

$7 \quad C 1202 C=.000250$

8 CONTIN DE

END P RO

$C 1402 C=C 1202 C * C 1402 A / C 1202 A$

* call aubient co2 concentration prou function chex

$+$

C1402A $=$ CHEX (A)

CC14A $=$ INTGRL $(0.0, C 1402 A)$

$*$

* calculate total grouth

$\star$

PROCEDORE RNP 12, RN P 14=PHOTO ( $L R T, C$ 1202C,C $1402 \mathrm{~A}$ )

IF ((TM .LT. TRNP) .OR . (TH .GT. TAB)) GO TO 3

IP (IT . EQ. 0.0 ) GO TO 3

RNP 12 $=(C 1202 A-C 1202 C) / L R T$

BNP1 $4=(C 1402 \mathrm{~A}-\mathrm{C} 1402 \mathrm{C}) / \mathrm{LRT}$

GO TO 4

$3 \quad$ R NP1 $2=0.0$

R NP 1 $14=0.0$

4 CONTIN OE

BUDP RO

$\mathrm{LRT}=\mathrm{L} R \mathrm{R}+\mathrm{LRI}$

$L$ RS $=1.7 * R$ R 20

TERM $3=\operatorname{BXP}(-B 2 * I X)$

$T B R M 4=E X P(-B 1 * T T)$

LRI = (P 1*TERM 3*TERA4) + P5

$C 1202 D=1.977 \mathrm{E}-3-6.5 \mathrm{E}-6 * \mathrm{TT}$

$C 1402 D=1.045 * C 1202 D$

RGR $12=R N P 12 * L A I * 3.6 E 7 * C 1202 D * C 12 C N V$ 


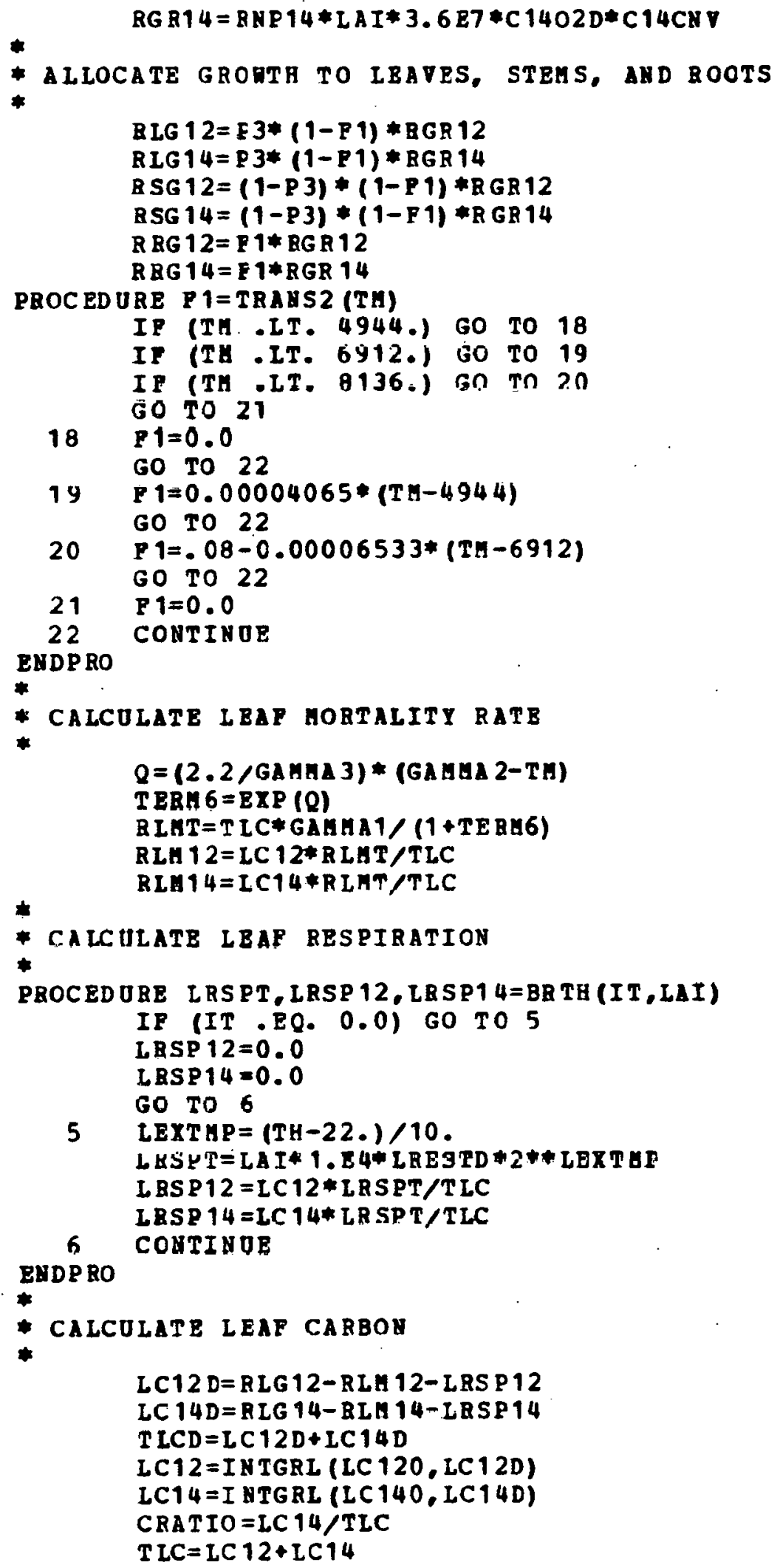




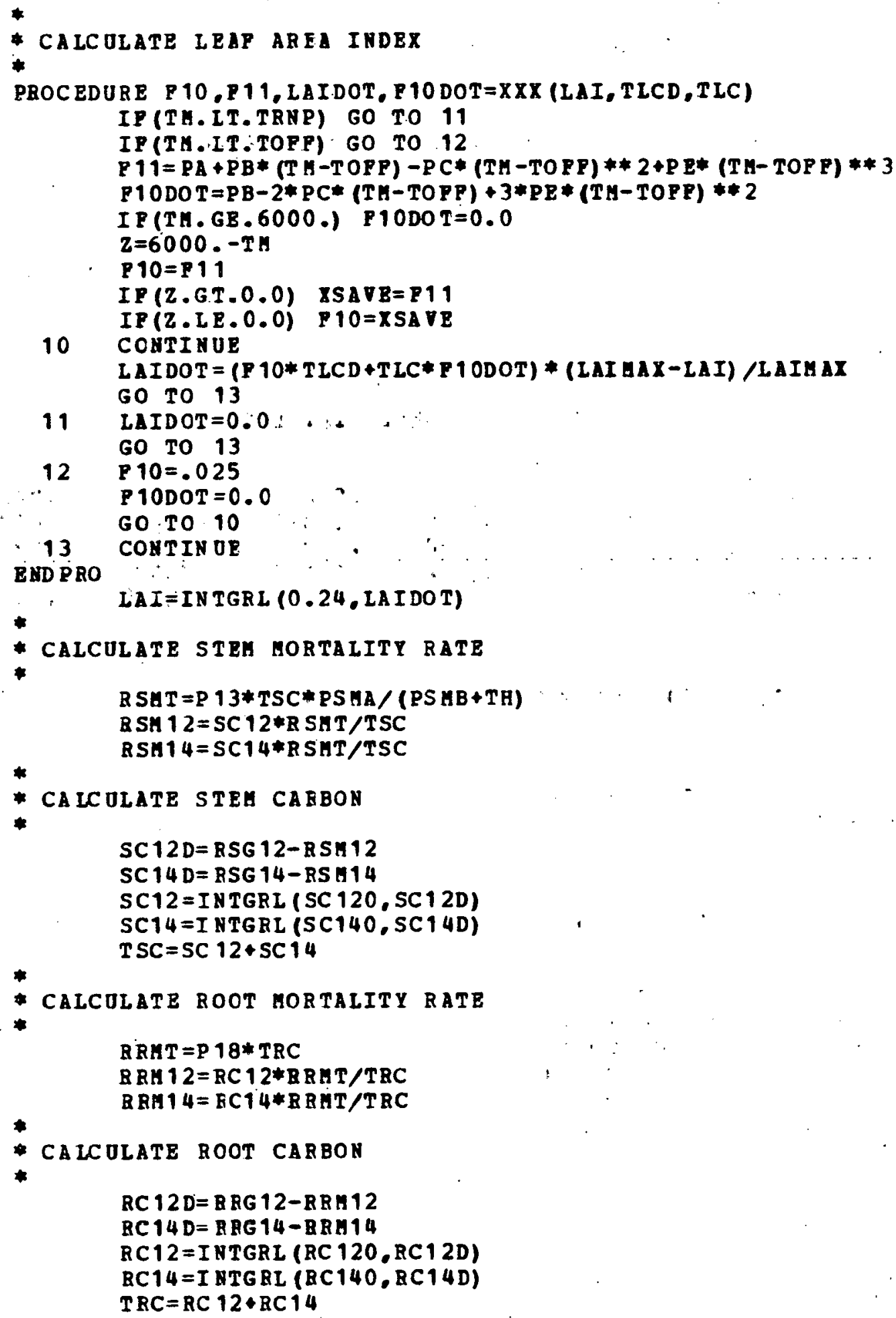

RC $12 D=R$ RG 12-RRH12

RC14D= ARG 14-BRH14

RC12 = I NTGRL (RC 120, RC12D) RC14 =I NTGRL (BC140, RC1 4D) $T R C=R C 12 \bullet R C 14$ 
$+$

calculate total plant carbon

$T P C=T L C+T S C+T R C$

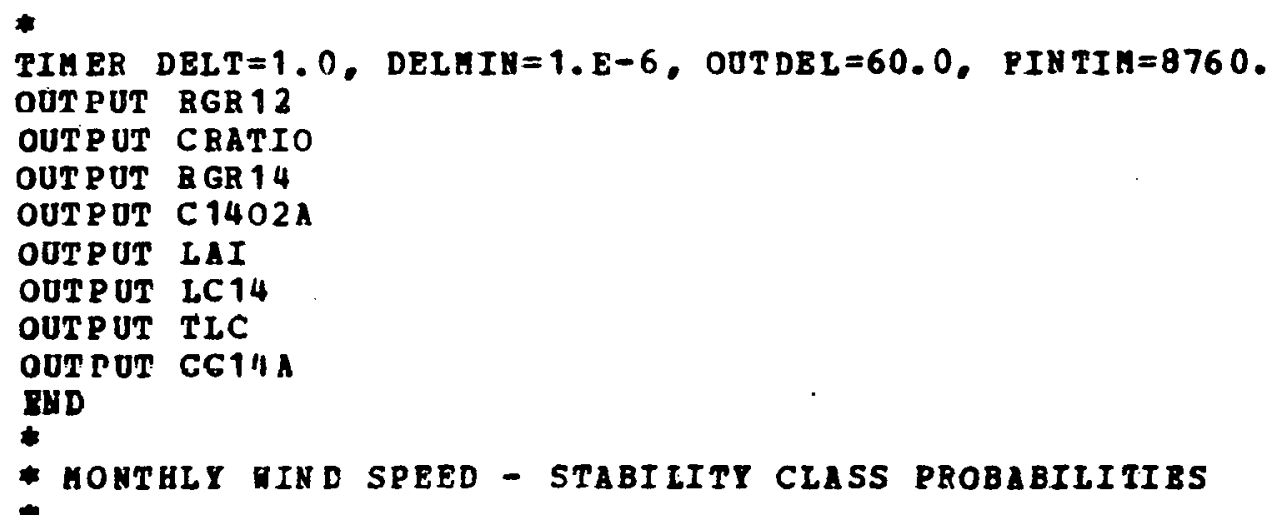


GLOSSARY OF VARIABLES AND PARAMETERS

Variables

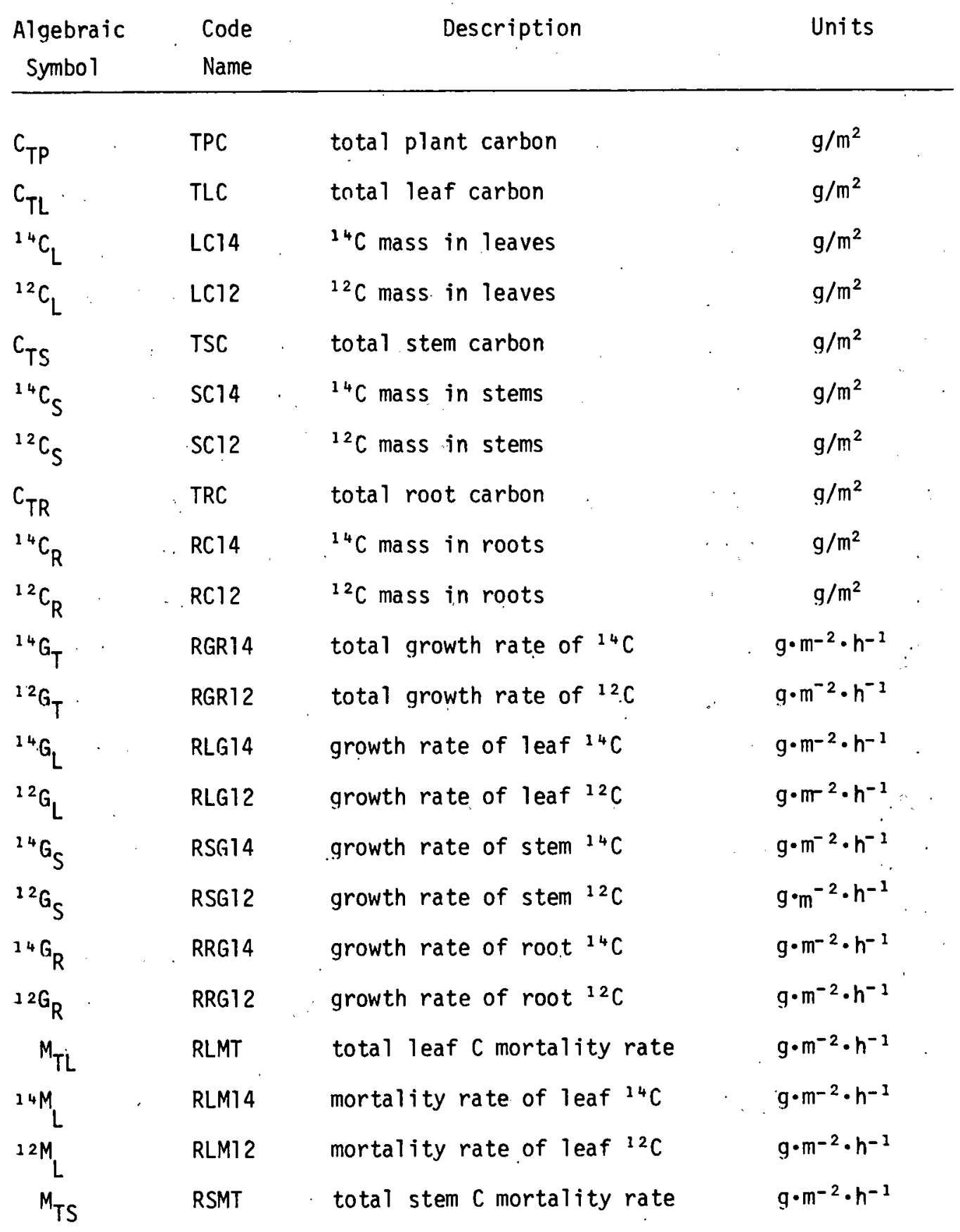




\begin{tabular}{|c|c|c|c|}
\hline $\begin{array}{c}\text { Algebraic } \\
\text { Symbol }\end{array}$ & $\begin{array}{l}\text { Code } \\
\text { Name }\end{array}$ & Description & Units \\
\hline${ }^{14} M_{S}$ & RSM14 & mortality rate of stem ${ }^{14} \mathrm{C}$ & $g \cdot m^{-2} \cdot h^{-1}$ \\
\hline${ }^{12} M_{S}$ & RSM12 & mortality rate of stem ${ }^{12} \mathrm{C}$ & $g \cdot m^{-2} \cdot h^{-1}$ \\
\hline$M_{T R}$ & RRMT & total root $C$ mortality rate & $g \cdot m^{-2} \cdot h^{-1}$ \\
\hline${ }^{24} M_{R}$ & RRMI4 & mortality rate of root ${ }^{14} \mathrm{C}$ & $g \cdot m^{-2} \cdot h^{-1}$ \\
\hline${ }^{12} M_{R}$ & RRM12 & mortality rate of root ${ }^{12} \mathrm{C}$ & $g \cdot m^{-2} \cdot h r^{-1}$ \\
\hline $\mathrm{R}_{\mathrm{TL}}$ & LRSPT & total leaf $C$ respiration rate & $g \cdot m^{-2} \cdot h r^{-1}$ \\
\hline${ }^{14} R_{L}$ & LRSP14 & respiration rate of leaf ${ }^{14} \mathrm{C}$ & $g \cdot m^{-2} \cdot h r^{-1}$ \\
\hline$\stackrel{12 R_{L}}{ }$ & LRSP12 & respiration rate of 1 eaf ${ }^{12} \mathrm{C}$ & $q \cdot m^{-2} \cdot h r^{-1}$ \\
\hline${ }^{\mathrm{R}} \mathrm{TS}$ & SRSPT & total stem $C$ respiration rate & $g \cdot m^{-2} \cdot h r^{-1}$ \\
\hline${ }^{14} R_{S}$ & SRSP14 & respiration rate of stem ${ }^{1{ }^{4}} \mathrm{C}$ & $g \cdot m^{-2} \cdot h r^{-1}$ \\
\hline${ }^{12} R_{S}$ & SRSP12 & respiration rate of stem ${ }^{12} \mathrm{C}$ & $g \cdot m^{-2} \cdot h r^{-1}$ \\
\hline $\mathrm{R}_{\mathrm{TR}}$ & RRSPT & total root $\mathrm{C}$ respiration rate & $g \cdot m^{-2} \cdot h r^{-1}$ \\
\hline${ }^{14} R_{R}$ & RRSP14 & respiration rate of $\operatorname{root}^{14} \mathrm{C}$ & $g \cdot m^{-2} \cdot h r^{-1}$ \\
\hline${ }^{12} \mathrm{R}_{\mathrm{R}}$ & RRSP12 & respiration rate of $\operatorname{root}^{12} \mathrm{C}$ & $g \cdot m^{-2} \cdot h r^{-1}$ \\
\hline${ }^{3} \cdot F_{v}$ & RNP14 & net volume flux of ${ }^{14} \mathrm{CO}_{2}$ & $\mathrm{~cm}^{3} \cdot \mathrm{cm}^{-2} \cdot \mathrm{s}^{-1}$ \\
\hline${ }^{12} F_{V}$ & RNP12 & net volume flux of ${ }^{12} \mathrm{CO}_{2}$ & $\mathrm{~cm}^{3} \cdot \mathrm{cm}^{-2} \cdot \mathrm{s}^{-1}$ \\
\hline${ }^{14} \mathrm{CO}_{2 \mathrm{a}}$ & C1402A & ambient concentration of ${ }^{14} \mathrm{CO}_{2}$ & $\mathrm{~cm}^{3} / \mathrm{cm}^{3}$ \\
\hline${ }^{14} \mathrm{CO}_{2 \mathrm{C}}$ & $6.1402 C$ & ${ }^{14} \mathrm{CO}_{2}$ conc. at the chloroplast & $\mathrm{cm}^{3} / \mathrm{cm}^{3}$ \\
\hline${ }^{12} \mathrm{CO}_{2 \mathrm{C}}$ & $\mathrm{Cl} 202 \mathrm{C}$ & ${ }^{12} \mathrm{CO}_{2}$ conc. at the chloroplast & $\mathrm{cm}^{3} / \mathrm{cm}^{3}$ \\
\hline${ }^{14} F_{m}$ & & net. mass flux of ${ }^{14} \mathrm{C}$ exchange & $\mathrm{g} \cdot \mathrm{cm}^{-2} \cdot \mathrm{hr}^{-1}$ \\
\hline${ }^{1}{ }^{2} \Gamma_{m}$ & & net mass flux of ${ }^{12} \mathrm{C}$ exchanye & $\mathrm{g} \cdot \mathrm{Cm}^{-3} \cdot \mathrm{hr}^{-1}$ \\
\hline LAI & LAI & leaf area Index & $m^{2} / m^{2}$ \\
\hline$\dot{\rho}$ & $\left\{\begin{array}{l}C 1202 D \\
C 1402 D\end{array}\right.$ & $\begin{array}{l}\text { density of pure }{ }^{12} \mathrm{CO}_{2} \\
\text { density of pure }{ }^{14} \mathrm{CO}_{2}\end{array}$ & $\begin{array}{l}\mathrm{g} / \mathrm{cm}^{3} \\
\mathrm{~g} / \mathrm{cm}^{3}\end{array}$ \\
\hline
\end{tabular}




\begin{tabular}{|c|c|c|c|}
\hline $\begin{array}{l}\text { Algebraic } \\
\text { Symbol }\end{array}$ & $\begin{array}{l}\text { Code } \\
\text { Name }\end{array}$ & Description & Units \\
\hline${ }^{14} \dot{C}_{L}$ & LCI4D & mass balance rate of leaf ${ }^{14} \mathrm{C}$ & $g \cdot m^{-2} \cdot h r^{-1}$ \\
\hline${ }^{12} \dot{C}_{L}$ & LCT2D & mass balance rate of leaf ${ }^{12} \mathrm{C}$ & $g \cdot m^{-2} \cdot h r^{-1}$ \\
\hline$\dot{C}_{\mathrm{TL}}$ & TLCD & $\begin{array}{l}\text { mass balance rate of total } \\
\text { leaf } C\end{array}$ & $g \cdot m^{-2} \cdot h r^{-1}$ \\
\hline${ }^{r} \mathrm{CO}_{2}$ & LRT & total $\mathrm{CO}_{2}$ transfer resistance & $\mathrm{s} / \mathrm{cm}$ \\
\hline$r_{i}$ & LRI & $\begin{array}{l}\text { apparent mesophyll } \mathrm{CO}_{2} \text { dif- } \\
\text { fusion resistance }\end{array}$ & $\mathrm{s} / \mathrm{cm}$ \\
\hline$r_{s}$ & LRS & $\begin{array}{l}\therefore \text { stomatal } \mathrm{CO}_{2} \text { diffusion } \\
\text { resistance }\end{array}$ & $\mathrm{s} / \mathrm{cIII}$ \\
\hline Io & IH & $\begin{array}{l}\text { average hourly incident } \\
\text { radiation }\end{array}$ & $\mathrm{cal} \cdot \mathrm{cm}^{-2} \cdot \min$ \\
\hline$T$ & $\mathrm{TH}$ & . average hourly air temperature & ${ }^{\circ} \mathrm{C}$ \\
\hline$I_{x}$ & IX & $\begin{array}{l}\text { average hourly radiant flux in } \\
\text { canopy }\end{array}$ & $\mathrm{cal} \cdot \mathrm{cm}^{-2} \cdot \mathrm{min}^{-}$ \\
\hline & CRATIO & $\begin{array}{l}\text { ratio of leaf }{ }^{14} \mathrm{C} \text { to total } \\
=\text { leaf } \mathrm{C}\end{array}$ & - \\
\hline & $\mathrm{Fl}$ & $\begin{array}{l}\text { fraction of photosynthate } \\
\text { allocated to roots }\end{array}$ & - \\
\hline$f_{10}$ & F10 & leaf area to leaf weight ratio & $\mathrm{m}^{2} / \mathrm{g}$ \\
\hline
\end{tabular}




\section{Parameters}

\begin{tabular}{|c|c|c|c|c|}
\hline $\begin{array}{l}\text { Algebraic } \\
\text { Symbol }\end{array}$ & $\begin{array}{l}\text { Code } \\
\text { Name }\end{array}$ & Description & Value & Units \\
\hline \multirow[t]{13}{*}{${ }^{12} \mathrm{CO}_{2 \mathrm{a}}$} & C1202A & ambient concentration of ${ }^{12} \mathrm{CO}_{2}$ & $3.4 \times 10^{-4}$ & $\mathrm{~cm}^{3} / \mathrm{cm}^{3}$ \\
\hline & C12CNV & $\begin{array}{l}\text { stoichiometric coefficient } \\
\text { to convert }{ }^{12} \mathrm{CO}_{2} \text { to }{ }^{12} \mathrm{C}\end{array}$ & .2714 & $g / g$ \\
\hline & C14CNV & $\begin{array}{l}\text { stoichiometric coefficient } \\
\text { to convert }{ }^{14} \mathrm{CO}_{2} \text { to }{ }^{14} \mathrm{C}\end{array}$ & .2642 & $g / g$ \\
\hline & ISTAR & $\begin{array}{c}\text { maximum avcrage hourly } \\
\text { incident radiation }\end{array}$ & $6.0 \times 10^{-6}$ & 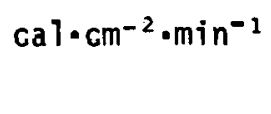 \\
\hline & $\mathrm{Pl}$ & $\begin{array}{l}\text { maximum apparent mesophyll } \\
\text { resistance }\end{array}$ & 200 & $\mathrm{~s} / \mathrm{cm}$ \\
\hline & P3 & $\begin{array}{l}\text { fraction of aboveground photo- } \\
\text { synthates allocated to leaves }\end{array}$ & 0.9 & - \\
\hline & $\mathbf{P} 5$ & $\begin{array}{l}\text { minimum apparent mesophy } 11 \\
\text { resistance }\end{array}$ & 15 & $\mathrm{~s} / \mathrm{cm}$ \\
\hline & P13 & $\begin{array}{l}\text { maximum hourl.y stem } \\
\text { mortality rate coefficient }\end{array}$ & $6.166 \times 10^{-5}$ & $h r^{-1}$ \\
\hline & . P18 & root mortality rate constant & $7.43 \times 10^{-5}$ & $h r^{-1}$ \\
\hline & RH2O & leaf transpiration resistance & 3.5 & $\mathrm{~s} / \mathrm{cm}$ \\
\hline & TRNP & time of start of growing season & 1800 & $\mathrm{hr}$ \\
\hline & TAB & time of end of growing season & 7224 & hr \\
\hline & LAIMAX & maximum leaf area index & 5.0 & $\mathrm{~m}^{2} / \mathrm{II}^{2}$ \\
\hline$R_{\text {std }}$ & LKESIU & stāndàd leaf respiration rate & $1.45 \times 10^{0}$ & $\mathrm{~g} \cdot \mathrm{CIII}^{-2} \cdot \mathrm{hr}^{-2}$ \\
\hline$\gamma_{1}$ & GAMMA1 & $\begin{array}{l}\text { maximum hourly leaf mortality } \\
\text { rate coefficient }\end{array}$ & .005 & $h r^{-1}$ \\
\hline$\gamma_{2}$ & GAMMA2 & time of maximum leaf fall & 7239.84 & hr \\
\hline$\gamma_{3}$ & GAMMA3 & $\begin{array}{l}\text { time between } 0.1 \text { and } 0.5 \\
\text { total leaf fall }\end{array}$ & 1248.00 & $\mathrm{hr}$ \\
\hline
\end{tabular}


ORNL/TM-5284

UC -41, UC -77

INTERNAL DISTRIBUTION

1-20. S. I. Auerbach

21. J. A. Auxier

22. C. J. Barton

23. F. T. Binford

24. R. E. Blanco

25. B. G. Blaylock

26. J. 0. Blomeke

27. R. A. Bradley

28. W. B. Cottrell

29. F. L. Culler

30. R. C. Dahiman

31. W. Davis, Jr.

32. C. E. Easterly

33. D. E. Fergus on

34. C. W. Francis

35. H. W. Godbee

36. W. R. Grimes

37. W. F. Harris, III

38. G. S. Hill

39. F. J. Homan

40. J. D. Jenkins

41-80. P. R. Kasten

81-90. S. V. Kaye

91. G. D. Kerr

92. G. G. Killough, Jr.
93. A. L. Lotts

94. R. E. Moore

95. K. J. Notz

96. J. S. 01son

97. D. C. Parzyck

98. W. H. Pechin

99. H. A. Pfuderer

100. H. Postma

101. J. W. Poston

102. D. E. Reichle

103. C. R. Richmond

104. J. W. Roddy

105. P. S. Rohwer

106. J. D. Sease

107. J. W. Snider

108. E. G. Struxness

109. T. Tamura

110. J. E. Till

111. R. I. Van Hook

112. J. P. Witherspoon

113. R. G. Wymer

114-116. Central Research Library

117. ORNL - Y-12 Technical

118-119. Laboratory Records Department

120. Laboratory Records, ORNL R.C.

121. ORNL Patent Office

\section{EXTERNAL DISTRIBUTION}

122. Lee Aamodt, Los Alamos Scientific Laboratory, P. 0. Box 1663, Los Alamos, New Mexico 87544.

123. Advanced Research Projects Agency, Department of Defense, The Pentagon, Washington, D. C. 20301.

124. L. R. Anspaugh, University of California, Lawrence Livermore Laboratory, Livermore, Cali fornia 94550.

125. R. F. Barker, Product Standards Branch, Directorate of Regulatory Standards, U.S. Nuclear Regulatory Commission, Washington, D. C. 20545.

126. Nathaniel F. Barr, Division of Biomedical and Environmental Research, U.S. Energy Research and Development Administration, Washington, D. C. 20545. 
127. D. S. Barth, National Environmental Research Center, EPA, P. 0. Box 15027, Las Vegas, Nevada 89114.

128. Martin B. Biles, Director, Division of Operational Safety, U.S. Nuclear Regulatory Commission, Washington, D. C. 20545.

129. Andre Bouville, United Nations, Scientific Committee on the Effects of Atomic Radiation, New York, New York 10016.

130. J. A. Broadway, Eastern Environmental Research Facility, P. 0. Box 61, Montgomery, Alabama 36101.

131. Carter D. Broyles, Department Manager, Test Sciences (7110), Sandia Corp., P. 0. Box 5800, Albuquerque, New Mexico 87115.

132. W. W. Burr, Jr., Division of Biology and Medicine, U.S. Energy Research and Development Administration, Washington, D. C. 20545.

133. Murray Calkins, National Environmental Kesearch Center, Environmental Protection Agency, Cincinnati, Ohio 45268.

134. M. W. Carter, Interdisciplinary Sciences, Georgia Institute of Technology, At lanta, Georgia 20332.

135. Eddie W. Chew, El Paso Natural Gas Co., P. 0. Box 1492, El Paso, Texas 79999.

136. J. G. Christian, Office of Radiation Programs, U.S. Environmental Protection Agency, 401 M St. SW, Washington, D. C. 20460.

137. Roger J. Cloutier, Special Training Division, Oak Ridge Associated Universities, Oak Ridge, Tennessee 37830.

138. R. G. Cochrel1, Manager, Licensing Division, Westinghouse Electric Corporation, P. 0. Box 158, Madison, Pennsylvania 15663.

139. Jerry Cohen, Lawrence Livermore Laboratory, P. 0. Box 808, Livermore, California 94551 .

140. Jared J. Davis, Office of Nuclear Regulatory Research, U.S. Nuclear Regulatory Commission, Washington, D. C. 20545.

141. Raymond D. Cooper, Division of Biomedical and Environmental Research, U.S. [nergy Research and Development Administration, Washington, D. C. 20545.

142. Paul J. Cory, Office of the Secretary of Transportation, Washington, D. C. 20590.

143. George A. Cowan, Los Alamos Scientific Laboratory, P. 0. Box 1663, Los Alamos, New Mexico 87544.

144. T. V. Crawford, Savannah River Laboratory, E. I. du Pont de Nemours \& Company, Aiken, South Carolina 29801.

145. R. G. Cuddihy, Inhalation Toxicology Research Institute, 5200 Gibson Blvd. SE, Albuquerque, New Mexico 87108.

146. Richard Cunningham, Division of Materials Licensing, U.S. Nuctear Regulatory Conmissiun, Bethesda, Maryland 20014.

147. L. J. Deal, Division of Biomedical and Environmental Research, U.S. Energy Research and Development Administration, Washington, D. C. 20545.

148. N. J. Diax, Dept. Nuclear Engineering Sciences, University of Florida, Gainesville, Florida 32601.

149. Richard L. Blanchard, Radiochemistry \& Nuclear Engineering Facility, U.S. Environmental Protection Agency, Cincinnati, Ohio 45268 . 
150. Dick Duffey, Nuclear Engineering, University of Maryland, 5614 Alta Vista Road, Bethesda, Maryland 20034.

151. P. B. Dunaway, Office of Effects Evaluation, Nevada Operations Office, U.S. Energy Research and Development Administration, Las Vegas, Nevada 87114.

152. G. G. Eichholz, School of Nuclear Engineering, Georgia Institute of Technology, Atlanta, Georgia 20332.

153. Edward H. Fleming, University of California, Lawrence Livermore Laboratory, Mail Stop L-1, Box 808, Livermore, California 94550.

154. R. Franklin, Division of Biomedical and Environmental Research, U.S. Energy Research and Development Administration, Washington, D. C. 20545.

155. Mahlon Gates, Manager, Nevada Operations Office, U.S. Energy Research and Development Administration, P. 0. Box 1676, Las Vegas, Nevada 99101.

156. F. A. Gifford, Jr., Air Resources Atmospheric Turbulence and Diffusion Laboratory, NOAA, Oak Ridge, Tennessee 37830.

157. Abraham S. Goldin, Kresge Center for Environmental Health, Harvard University, School of Public Health, Boston, Massachusetts 02100 .

158. Marvin Goldman, University of California, Davis, California 95616.

159. R. S. Goor, National Science Foundation, 2101 Constitution Ave., Washington, D. C. 20418.

160. R. L. Gotchy, Directorate of Licensing, U.S. Energy Research and Development Administration, Washington, D. C. 20545.

161. Douglas Grahn, Argonne National Laboratory, 9700 South Cass Avenue, Argonne, 111 inois 60439.

162. Richard Graves, Assistant Superintendent, Connecticut Yankee Nuclear Power Station, RR\#1, Box 127E, East Hampton, Connecticut 06424.

163. Harold J. Groh, Jr., Separations Chemistry, Savannah River Laboratory, E. I . duPont de Nemours and Company, P. 0. Box "A", Aiken, South Carolina 29802.

164. J. E. Hardaway, Surveillance and Analysis Division, Technical Support Branch, Suite 900, 1860 Lincoln Street, Denver, Colorado 80203.

165. Monte Hawkins, Head, Safety and Environmental Control, Allied General Nuclear Services, P. 0. Box 847, Barnwe11, South Carolina 29812.

166. J. W. Healy, Health Physics Division, Los Alamos Scientific Laboratory, Box 1663, Los Alamos, New Mexico 87544.

167. Gary H. Higgins, K. Division, Lawrence Livermore Laboratory, P. 0. Box 808 (L-41), Livermore, California 94551.

168. George Hinman, Gulf Central Atomic, Box 608, San Diego, California 92112 .

169. I. A. Hobbs, Director, Technical and Production Division, Savannah River Operations Office, P. 0. Box "A", Aiken, South Carolina 29802. 
170. John B. Hursh, Department of Radiation Biology and Biophysics, University of Rochester, Rochester, New York 14620.

171. Stephen Jinks, Institute of Environmental Medicine, New York University Medical Center, Long Meadow Road, Tuxedo, New York 10987.

172. B. Kahn, Interdisciplinary Sciences, Georgia Institute of Technology, Atlanta, Georgia 20332.

173. Jacob Kastner, Environmental Standards Branch, Directorate of Licensing, U.S. Nuclear Regulatory Commission, Washington, D. C. 20545.

174. J. Kline, Argonne National Laboratory, Radiological Physics Division Ecological Studies, Argonne, Illinois 60439.

175. J. Koranda, Biomedical Division, Lawrence Radiation Laboratory, P. 0. Box 808 ( $L-13)$, Livermore, California 94551 .

176. Paul Kruger, Professor of Nuclear Chemistry, Department of Civil Engineering, Stanford University, Stanford, California.

177. William Martin, Battelle Memorial Institute, 505 King Avenue, Columbus, Ohio 43201.

178. P. J. Mellinger, EXXON Nuclear Company, 2955 George Washington Way, Richland, Washington 99352.

179. Peter MCGrath, ORG 1721, Sandia Laboratories, Albuquerque, New Mexico 87113.

180. W. A. Mills, U.S. Environmental Protection Agency, Criteria and Standards Division, 401 M St., SW, Washington, D. C. 20460.

181. M. T. Mi11s, GCA Technical Division, Burlington Road, Bedford, Massachusetts 01730 .

182. A. A. Moghissi, Office of Interdisciplinary Studies, Georgia Institute of Technology, Atlanta, Georgia 20332.

183. K. Z. Morgan, School of Nuclear Engineering, Georgia Institute of Technology, Atlanta, Georgia 20332.

184. Henry W. Morton, Nuclear Fuel Services, Inc., 6000 Executive Rlvd. Suite 600 , Rockville, Maryland 20852.

185. D. R. Nelson, Office of Radiation Programs, U.S. Environmental Protection Agency, $401 \mathrm{M}$ Street, S. W., Washington, D. C. 20460.

186. T. R. Noonan, UT-AEC Agricultural Research Laboratory, 1299 Bethel Valley Road, Ọak. Ridge, Tennessee 37830.

187. H. T. Odum, Department of Environmental Engineering, University of Florida, Gainesville, Florida 32601.

188. W. Ogle, Los Alamos Scientific Laboratory, P. 0. Box 1663, Los Alamos, New Mexico 87544.

189. M. J. Ohanian, Head, Department of Nuclear Engineering Sciences, University of Florida, Gainesville, Florida 32601.

190. W. S. Osburn, Division of Biomedical and Environmental Research, U.S. Energy Research and Development Administration, Washington, D. C. 20545.

191. Charles Osterberg, Division of Biomedical and Environmental Research, U.S. Energy Research and Development Administration, Washington, D. C. 20545.

192. Aaron Padgett, Carolina Power and Light, P.0. Box 1551, Raleigh, North Carolina 27602. 
193. C. C. Palmiter, Office of Radiation Programs, Environmental Protection Agency, 401 M Street, SW, Washington, D. C. 20460.

194. F. L. Parker, Department of Civil Engineering, Vanderbilt University, Nashville, Tennessee 37203.

195. Michae1 A. Parsont, Radiological Assessment Branch, Directorate of Licensing, U.S. Nuclear Regulatory Commission, Washington, D. C. 20545.

196. H. R. Payne, U.S. Environmental Protection Agency Region IV, 1421 Peachtree St., Atlanta, Georgia 30309.

197. W. H. Pennington, Division of Biomedical and Environmental Research, U.S. Energy Research and Development Administration, Washington, D. C. 20545.

198. Paul Phelps, University of California, Lawrence Radiation Laboratory, Livermore, California 94550.

199. J. F. Phillip, Director, Special Projects Division, San Francisco Operations Office, Energy Research and Development Administration, 2111 Bancroft Way, Berkeley, California 94704.

200. K. Purushothamon, University of Missouri at Rolla, Rolla, Missouri. 64501.

201. C. J. Roberts, School of Nuclear Engineering, Georgia Institute of Technology, Atlanta, Georgia 20332.

202. J. N. Rogers, Division 8321, Sandia Laboratories, P. 0. Box 969, Livermore, California 94550.

203. Milton E. Rose, Mathematical and Computer Sciences Program, Molecular Sciences and Energy Research, Division of Physical Research, U.S. Energy Research and Development Administration, Washington, D. C. 20545.

204. H. C. Rothschild, Radiation Protection Bureau, Brookfield Road, Ottawa $\mathrm{KlAlCl}$, Ontario, Canada.

205. Paul Russe11, Research Director, Denver Mining Research Center, U.S. Bureau of Mines, Denver Federal Building, Denver, Colorado 80225.

206. Lewis M. Schalit, Systems, Science and Software, P. 0. Box 1620, La Jolla, California 92037.

207. Keith J. Schiager, University of Pittsburgh, Radiation Center, Pittsburgh, Pennsylvania 15213.

208. G. A. Selmel, Division of Biology and Medicine, Battelle Pacific Northwest Laboratories, Richland, Washington 99352.

209. Clifford S. Selvage, Manager, Advance Systems Research Department 1, Sandia Corp., P. 0. Box 969, Livermore, California 94550.

210. C. F. Smith, Jr., Lawrence Livermore Laboratory, P. 0. Box 808, Livermore, California 94551.

211. David S. Smith, Office of Radiation Programs, U.S. Environmental Protection Agency, 401 M Street, SW, Washington, D. C. 20460.

212. J. K. Soldat, Pacific Northwest Laboratories, Battelle Memorial Institute, Richland, Washington.

213. Jeff Swinebroad, Division of Biomedical and Environmental Research, U.S. Energy Research and Development Administration, Washington, D. C. 20545.

214. Lauriston Taylor, National Academy of Sciences, Advisory Committee on Emergency Planning, 2101 Constitution Avenue, Washington, D. C. 20418. 
215. Howard Towes, Lawrence Livermore Laboratory, P. 0. Box 808, Livermore, California 94551.

216. Paul C. Tompkins, 407 Clayton Road, Chapel Hill, North Carolina 27514.

217. A. N. Tse, Product Standards Branch, Directorate of Regulatory Standards, U.S. Nuclear Regulatory Commission, Washington, D. C. 20545.

218. B. H. Van Domelen, Governor's Science Adviser, Sandia Laboratory, 1820, Albuquerque, New Mexico 87115.

219. R. Watters, Division of Biomedical and Environmental Research, U.S. Energy Research and Development Administration, Washington, D. C. 20545.

220. James E. Watson, Jr., Radiological Hygiene Branch, Tennessee Valley Authority, River Oaks Building, Muscle Shoals, Alabama 35630 .

221. Alvin M. Weinberg, Institute for Energy Analysis, Dak. Ridge Associated Universities, Oak Ridge, Tennessee 37830.

222. F. W. Whicker, Department of Radiology and Radiation Biology, Colorado State University, Ft. Collins, Colorado 80521.

223. B. G. Wixson, University of Missouri at Rolla, Rolla, Missouri 65401.

224. R. W. Wood, Division of Biology and Medicine, U. S. Energy Research and Development Administration, Washington, D. C. 20545.

225. S. Yaniv, Office of Nuclear Regulatory Research, Mail Stop Al-3002, U.S. Nuclear Regulatory Commission, Washington, D. C. 20555 .

226. Research and Technical Support Division, ERDA-ORO, Oak Ridge, Tennesege 37830.

227-548. Given distribution as shown in TID-4500 under categories UC-41 and UC-77. 